\title{
Estimated 100-Year Peak Flows and Flow Volumes in the Big Lost River and Birch Creek at the Idaho National Engineering Laboratory, Idaho
}

By L.C. Kjelstrom and Charles Berenbrock

\section{U.S. GEOLOGICAL SURVEY}

Water-Resources Investigations Report 96-4163

Prepared in Cooperation with the

U.S. Department of Energy

Boise, Idaho

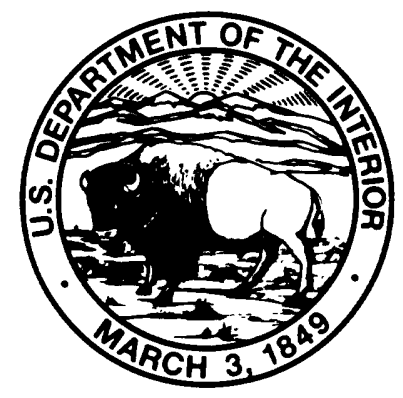




\section{U.S. DEPARTMENT OF THE INTERIOR \\ BRUCE BABBITT, Secretary \\ U.S. GEOLOGICAL SURVEY \\ Gordon P. Eaton, Director}

District Chief

U.S. Geological Survey

230 Collins Road

Boise, ID 83702-4520
U.S. Geological Survey

Information Services

Box 25286

Federal Center

Denver, CO 80225 


\section{CONTENTS}

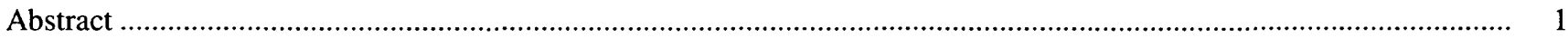

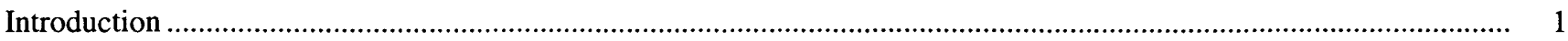

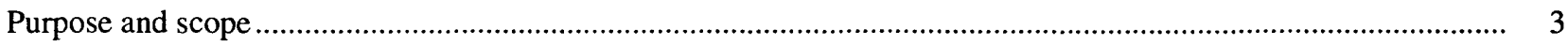

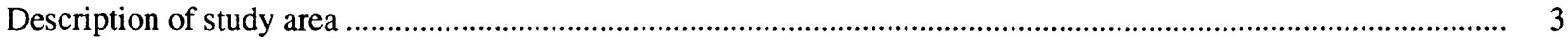

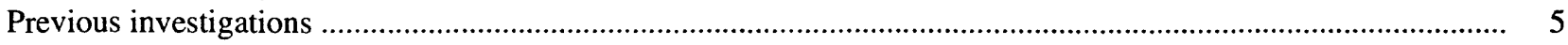

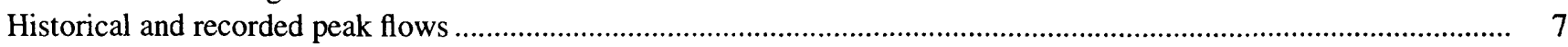

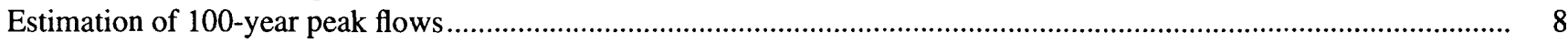

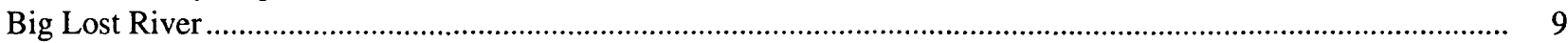

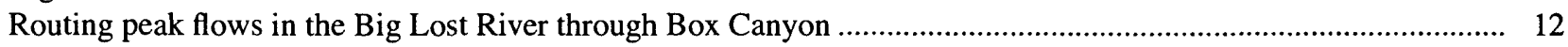

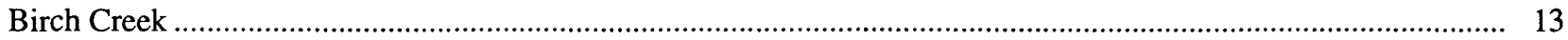

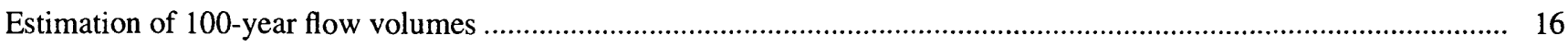

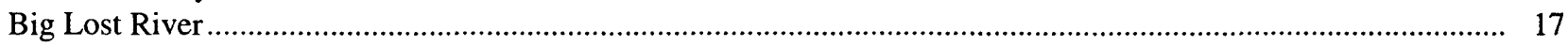

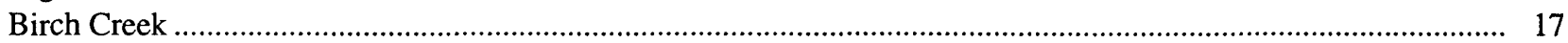

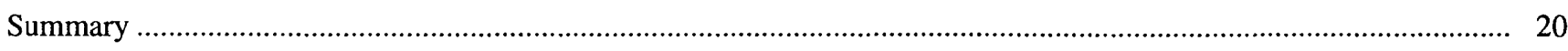

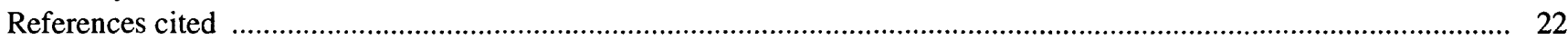

\section{FIGURES}

1. Map showing locations of study area, selected basins, and streamflow-gaging stations on the Big Lost River, Birch Creek, and nearby streams.

2. Map showing locations of Big Lost River Basin, subbasins, and streamflow-gaging stations.....................................

3. Map showing locations of Birch Creek Basin, subbasins, and streamflow-gaging stations ........................................ 6

4. Graph showing simulated 48-hour streamflow hydrographs for a 100-year peak flow at the Arco gaging station routed through Box Canyon to the INEL boundary.....

5. Graph showing simulated 2-hour streamflow hydrographs for a 100-year peak flow at the Arco gaging station routed through Box Canyon to the INEL boundary.

\section{TABLES}

1. Estimates of 100-year peak flow from subbasins of the Big Lost River between the Howell Ranch (13120500) and Arco (13132500) gaging stations

2. Estimated peak flows at selected gaging stations and from contributing subbasins in the Big Lost River Basin and estimated channel-infiltration losses from the Big Lost River for selected recurrence intervals.

3. Estimates of 100-year peak flow from subbasins of Birch Creek between the Reno gaging station (13117000) and Birch Creek Sinks

4. Estimated peak flows at gaging stations and other selected sites in the Birch Creek Basin at selected recurrence intervals

5. Values for 60 -day flow hydrographs and daily estimates of 100 -year peak flow volumes at selected gaging stations and from contributing subbasins in the Big Lost River Basin.

6. Values for 60-day flow hydrographs and daily estimates of 100 -year peak flow volumes at the Medicine Lodge Creek at Ellis Ranch, near Argora, gaging station and at selected gaging stations and sites in the Birch Creek Basin. 
CONVERSION TABLE

\begin{tabular}{rcl}
\hline Multiply & By & To obtain \\
\hline acre & 4,047 & square meter \\
acre-foot $(\mathrm{acre}-\mathrm{ft})$ & 1,233 & cubic meter \\
cubic foot per second $\left(\mathrm{ft}^{3} / \mathrm{s}\right)$ & 0.02832 & cubic meter per second \\
foot $(\mathrm{ft})$ & 0.3048 & meter \\
foot per mile $(\mathrm{ft} / \mathrm{mi})$ & 0.1894 & meter per kilometer \\
inch (in.) & 25.4 & millimeter \\
mile $(\mathrm{mi})$ & 1.609 & kilometer \\
square mile $\left(\mathrm{mi}^{2}\right)$ & 2.590 & square kilometer
\end{tabular}

Sea Level: In this report "sea level" refers to the National Geodetic Vertical Datum of 1929-a geodetic datum derived from a general adjustment of the first-order level nets of the United States and Canada, formerly called Sea Level Datum of 1929. 


\title{
Estimated 100-Year Peak Flows and Flow Volumes in the Big Lost River and Birch Creek at the Idaho National Engineering Laboratory, Idaho
}

\author{
By L.C. Kjelstrom and Charles Berenbrock
}

\section{Abstract}

Peak flows and flow volumes with recurrence intervals of 100 years for the Big Lost River and Birch Creek were estimated so that the extent of the 100-year flood plain at the Idaho National Engineering Laboratory could be delineated. Flows entering the Idaho National Engineering Laboratory area were estimated from flood-frequency analysis of data at gaging stations, from regional regression equations, and from channelinfiltration losses. The one-dimensional flow model FOURPT was used to route peak flow through a deep, basalt gorge between the Arco gaging station and the Idaho National Engineering Laboratory boundary. Results indicated that no adjustments to attenuation of the peak were needed at the Idaho National Engineering Laboratory's western boundary.

Estimates of flow volumes entering the Idaho National Engineering Laboratory area were made by using representative hydrographs at selected gaging stations. Representative hydrographs were developed by fitting the 1-, 3-, 7-, 15-, 30-, and 60day mean flows having a recurrence interval of 100 years to a smooth curve. Estimated peak flow for a recurrence interval of 100 years entering the boundary of the Idaho National Engineering Laboratory from the Big Lost River was 7,260 cubic feet per second. The estimated volume of flow for a 60-day period for a recurrence interval of 100 years was 390,000 acre-feet. For Birch Creek, the estimated peak flow for a recurrence interval of
100 years entering the Idaho National Engineering Laboratory area was 700 cubic feet per second, and the estimated 60-day volume of flow with a recurrence interval of 100 years was about 10,600 acre-feet.

In the next phase of this flood-plain delineation study, the 100-year peak flow will be routed downstream to spreading areas and playas in the Idaho National Engineering Laboratory area using a computer model to delineate the extent of the 100 -year flood plain.

\section{INTRODUCTION}

The Big Lost River and Birch Creek flow onto the eastern Snake River Plain (fig. 1) and terminate in playas, sinks, and spreading areas at the Idaho National Engineering Laboratory (INEL). Floods occur when streambanks can no longer contain streamflow. Although these streams rarely flood, peak flows and volumes from these rare periods of high streamflow need to be determined so the extent of the flood plain can be delineated to evaluate the potential severity of floods at INEL facilities.

The Big Lost River is the most likely source of flooding at the INEL. Natural water yield from the Big Lost River Basin is about seven times greater than that of the Birch Creek Basin (Kjelstrom, 1986, sheet 2). Mackay Reservoir, 45 mi upstream from the INEL, stores water from the Big Lost River for irrigation. Most of the water stored in the reservoir and most of the tributary inflow between the reservoir and Arco are diverted for irrigation or lost by infiltration through the 


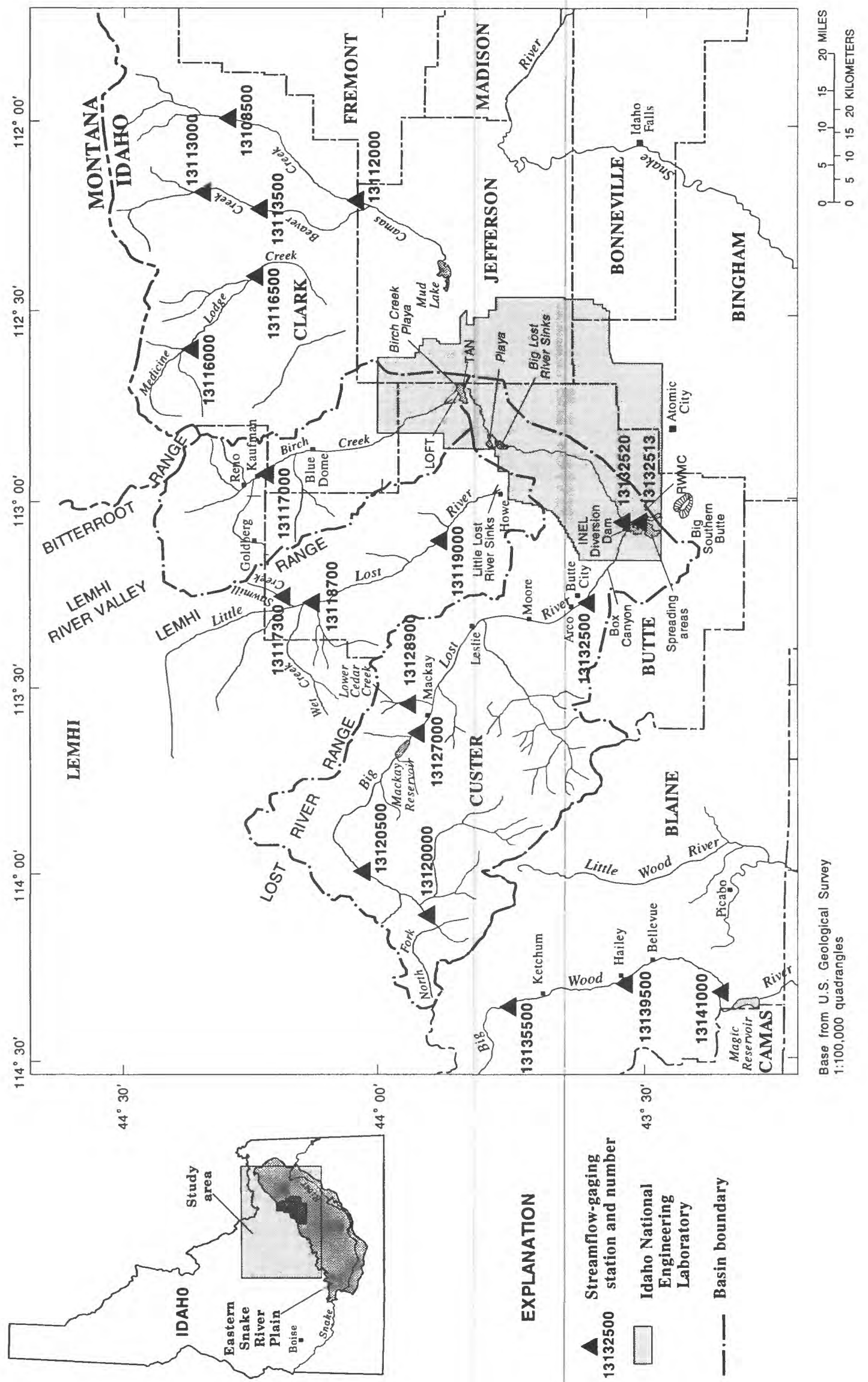

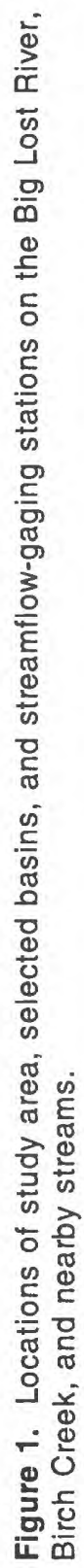


channel bottom to the alluvial valley fill. Thus, the streamflow-gaging station, Big Lost River near Arco (13132500), records little or no streamflow throughout most of the year. Streamflow that does reach this gaging station is depleted further by infiltration through the channel bottom downstream from Arco.

The Little Lost River flows onto the eastern Snake River Plain near Howe (fig. 1) from a drainage basin between the Big Lost River and Birch Creek Basins. Topographic maps indicate that flood water from the Little Lost River would flow eastward toward the Big Lost River playas. However, flow past the sinks at the terminus of the Little Lost River is not likely because of large irrigation diversions and infiltration losses in the valley upstream from the sinks. No INEL facilities exist in the Little Lost River drainage basin, and the terminus of the river is outside the INEL boundary. Thus, for the purposes of this study, the Little Lost River was considered to have a negligible potential for flooding facilities at the INEL.

Birch Creek flows southward through a long, alluvium-filled valley to the eastern Snake River Plain. Birch Creek has several small diversions for irrigation and one diversion to a power-generation facility. As in the Big Lost River channel, infiltration losses to alluvial valley fill are large. As a result of diversions and infiltration losses, Birch Creek rarely flows into the Birch Creek Playa at the north end of the INEL until flood conditions prevail.

In 1994, the U.S. Department of Energy at the INEL entered into a cooperative agreement with the U.S. Geological Survey to delineate the extent of possible flooding at the INEL from peak flows with recurrence intervals of 100 years from the Big Lost River and Birch Creek.

Four steps are planned for the flood-plain delineation study: (1) Determine 100-year recurrence interval peak flows and associated flow volumes. (2) Survey flood-plain cross sections to provide data needed for one- and two-dimensional models that will characterize the flow capacity of the stream channels and floodplain areas. (3) Use the one-dimensional model WaterSurface PROfile (WSPRO) to calculate the water-surface profiles and delineate the 100-year flood plain of Birch Creek, and to determine the areal extent of the grid for the two-dimensional model. (4) Use a twodimensional surface-water model to calculate watersurface profiles and delineate the 100-year flood plain of the Big Lost River.

\section{Purpose and Scope}

The purpose of this report is to provide estimates of the 100-year peak flows and flow volumes that could enter the INEL area from the Big Lost River and Birch Creek. The 100-year peak flows for the Big Lost River and Birch Creek are needed as input data for models that will be used to delineate the extent of the 100-year flood plain at the INEL. The methods, procedures, and assumptions used to estimate the 100 -year peak flows and flow volumes are described in this report.

\section{Description of Study Area}

The Big Lost River and Birch Creek Basins are located on the north side of the eastern Snake River Plain (fig. 1), about 50 mi west of Idaho Falls. These basins trend northwest-southeast and are bounded by mountains except at their southeastern ends, where they merge with the eastern Snake River Plain. Big Lost River terminates in four playas (the last playa is the Birch Creek Playa) with connecting channels that are in the INEL area (fig. 1). Birch Creek terminates at the Birch Creek Playa near Test Area North (TAN) and Loss of Fluid Test (LOFT) facilities (fig. 1). Basaltic lava flows underlie much of the Snake River Plain and prevent streamflow from these basins from reaching the Snake River. Consequently, all streamflow that flows onto the eastern Snake River Plain from the Big Lost River and Birch Creek either evaporates or infiltrates into the ground.

Much of the 1,410-mi drainage area in the Big Lost River Basin upstream from the gaging station near $\operatorname{Arco}(13132500$, fig. 2 ) is mountainous. The elongate valley is about 2 to $10 \mathrm{mi}$ wide, $50 \mathrm{mi}$ long, and partly filled with alluvium. The valley floor is relatively flat. The valley width between Mackay Reservoir (fig. 2) and Arco ranges from $0.3 \mathrm{mi}$ just below the dam to 6 mi near Arco. Land surface altitude ranges from about 5,300 ft above sea level near Arco to more than $12,600 \mathrm{ft}$ in the Lost River Range (fig. 1). Although the mean altitude of the basin is $7,700 \mathrm{ft}$ and the mean precipitation is about $20 \mathrm{in} / \mathrm{yr}$, the mean altitude of the valley is about $6,000 \mathrm{ft}$ and mean precipitation is about $10 \mathrm{in} / \mathrm{yr}$. Precipitation is fairly evenly distributed throughout the year. Flow in the Big Lost River near Arco is ephemeral because of climate, irrigation diversions, and channel infiltration. 


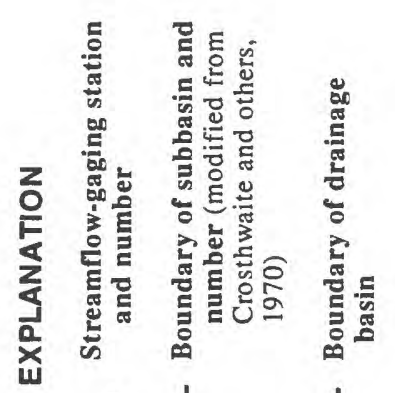

$\int \mid$

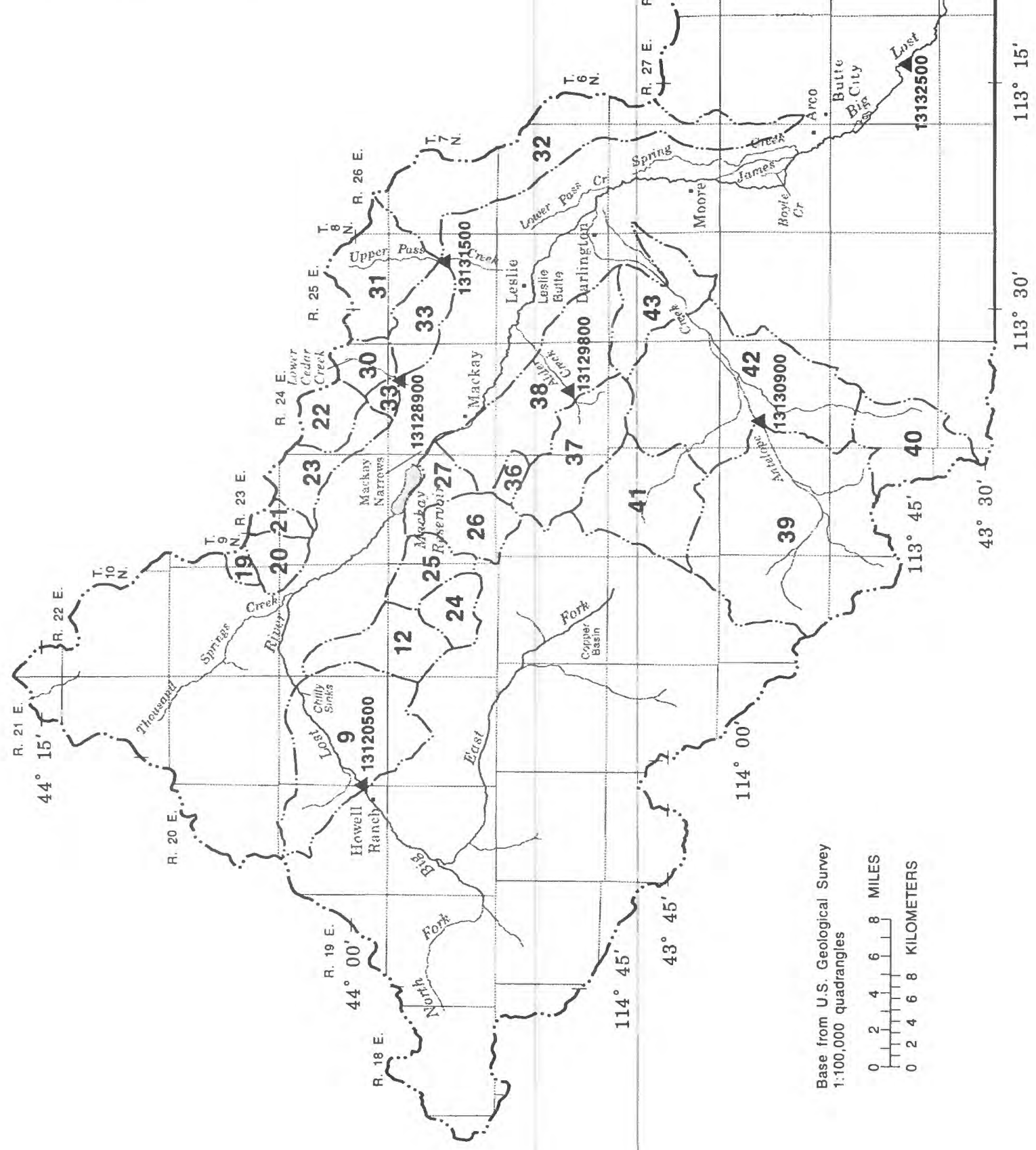

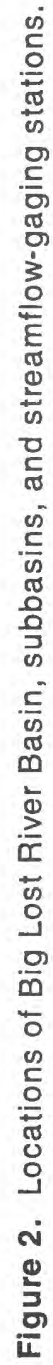


The communities of Mackay, Leslie, Moore, Arco, and Butte City (fig. 2) had a combined population of about 2,800 in 1992 . The town of Arco, with a population of about 1,030 , covers $1 \mathrm{mi}^{2}$ in the southeastern part of the basin.

Mackay Reservoir, about 30 mi northwest of Arco, is about halfway between the headwaters of the Big Lost River and Arco. Most surface-water inflow to Mackay Reservoir is the result of melting snowpacks. Active storage of Mackay Reservoir has decreased from 43,500 acre-ft in 1956 to about 38,500 acre-ft in 1980 (Williams and Krupin, 1984; U.S. Army Corps of Engineers, 1991) because of sedimentation. Water is stored in Mackay Reservoir to irrigate about 33,000 acres during the irrigation season (April through October).

Several miles downstream from the Arco gaging station, the Big Lost River enters Box Canyon, a deep, narrow gorge with nearly vertical walls cut into basaltic rocks. The canyon is about $7.5 \mathrm{mi}$ long and averages about $125 \mathrm{ft}$ wide and $75 \mathrm{ft}$ deep. After exiting Box Canyon, the channel cuts through alluvial fill covering basalt and crosses the western boundary of the INEL.

In 1958, a flood-control diversion system was constructed at the INEL to reduce the threat of floods from the Big Lost River. Water from the diversion channel can be stored in a connected series of spreading areas. About $18 \mathrm{mi}$ downstream from the diversion dam, the Big Lost River channel strikes north to the Big Lost River Sinks and terminates in a series of playas that are connected by branching channels.

The Birch Creek Basin lies between the Lemhi Range on the west and the Bitterroot Range on the east. The Birch Creek Valley is about 2 to $10 \mathrm{mi}$ wide and about $40 \mathrm{mi}$ long (fig. 3). A low ridge separates the Lemhi River Valley on the north and the Birch Creek Valley on the south. Because prevailing winds are from the west, precipitation in the Birch Creek Basin is less than in the Big Lost River Basin. Mean annual precipitation is less than 10 in. in Birch Creek Valley, 17 in. in the uplands and mountains of the Lemhi Range, and $15 \mathrm{in}$. in the uplands and mountains of the Bitterroot Range. Birch Creek is a perennial stream that is fed by springs upstream from the Birch Creek near Reno gaging station (13117000). Communities in the Birch Creek Basin include Reno, Kaufman, and Blue Dome. Their combined population in 1992 was about 300 .

About $15 \mathrm{mi}$ downstream from the Reno gaging station, diversion works divert flow from Birch Creek to a channel that leads to a hydroelectric power-gener- ating facility several miles east of Birch Creek. Flow to this power facility during the nonirrigation season is returned to Birch Creek several miles south of Highway 22 at a gravel pit.

About 10 mi southeast from where Birch Creek crosses the INEL boundary, the channel transforms into a large, shallow playa known as the Birch Creek Playa. The LOFT and TAN facilities are located near the playa's perimeter. The area between the gravel pit that is about 1 mi north of LOFT and the Birch Creek Playa is known as "Birch Creek Sinks" (fig. 3). No flow from Birch Creek has reached the Birch Creek Sinks since 1969, when several feet of water accumulated in the playa as a result of snowmelt from the lower Birch Creek Valley (Koslow, 1984). In response, the INEL built channels in 1969 to divert Birch Creek to several gravel pits and from there to sinks northeast of the playa. Dikes also were built to protect TAN and LOFT.

\section{Previous Investigations}

The earliest study of surface-water resources in the Big Lost River Basin was by Wright (1903). He briefly discussed gains and losses in the Big Lost River, including the influence of irrigation. The first comprehensive hydrologic study was by Stearns and others (1938). They described water resources of the Big Lost River Basin and estimated surface- and ground-water outflow from the area as part of a study of the eastern Snake River Plain. Mundorff and others (1964) discussed ground- and surface-water relations in the Big Lost River Basin and the basin's importance as a source of recharge to the eastern Snake River Plain. Barraclough and others (1967) studied mainly the ground-water resources of the INEL area but also discussed surface- and ground-water relations of the Big Lost River in the INEL area. Lamke (1969) developed stage-discharge relations for the Big Lost River at the diversion channel and the channels between each spreading area and playa. Crosthwaite and others (1970) described and provided new information on the geohydrology of the Big Lost River Basin. They also determined surface-water outflow from 44 subbasins to develop ground-water budgets for the valley. Williams and Krupin (1984) investigated erosion and sediment transport in the Big Lost River upstream from Mackay Reservoir. Bennett (1986) updated the stage-discharge relation at the diversion channel because the diversion 


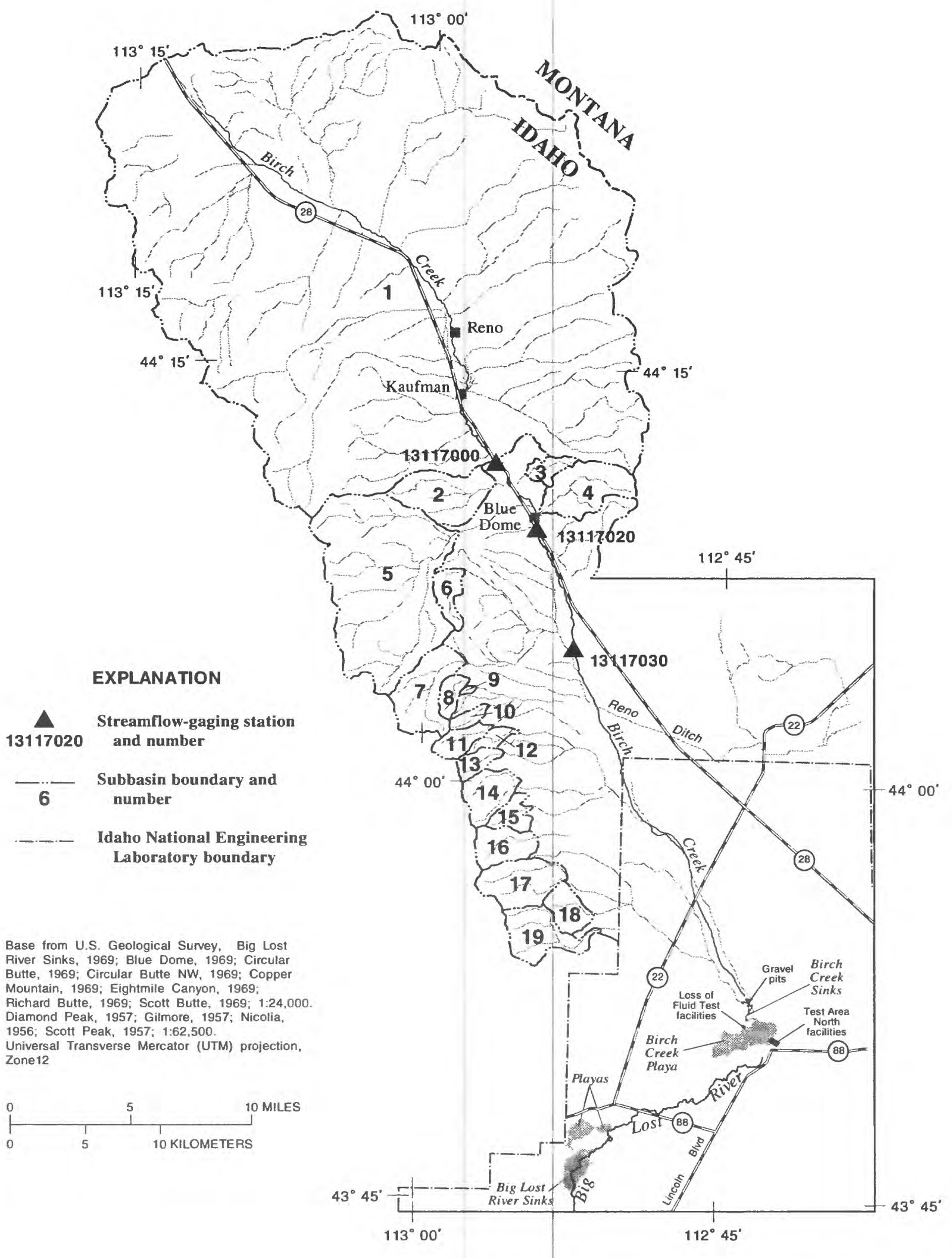

Base from U.S. Geological Survey, Big Lost River Sinks, 1969; Blue Dome, 1969; Circular Butte, 1969; Circular Butte NW, 1969; Coppe Mountain, 1969; Eightmile Canyon, 1969;

Richard Butte, 1969; Scott Butte, 1969; 1:24,000

Diamond Peak, 1957: Gilmore, 1957; Nicolia

1956; Scott Peak, 1957; 1:62,500.

Universal Transverse Mercator (UTM) projection, Zone 12

Figure 3. Locations of Birch Creek Basin, subbasins, and streamflow-gaging stations. 
channel was enlarged, and the dam and dikes were raised in 1984 to provide additional flood control. Bennett (1990) described channel-infiltration losses along the Big Lost River at the INEL. Koslow (1984) analyzed flooding from the Birch Creek Basin near LOFT and TAN. She determined that the 500-year flood would not cause water to pond in Birch Creek Playa near LOFT and TAN, but for the probable maximum flood, water would be within $2 \mathrm{ft}$ of the escape tunnel at LOFT in the Birch Creek Playa.

The U.S. Army Corps of Engineers (1967) described the conditions and extent of the June-July 1967 flood in the Big Lost River. The analysis did not extend downstream from Arco. The Corps (1991) also investigated the feasibility of reducing flood damages in the Big Lost River Valley. Carrigan (1972), Druffel and others (1979), Noble (1980), and Koslow and Van Haaften (1986) examined the hypothetical failure of Mackay Dam and the behavior of flood waves downstream by using flood-routing techniques. For the principal case of dam failure, the attenuated peak at the INEL boundary (about $45 \mathrm{mi}$ downstream from the dam) was estimated to be about $45,000 \mathrm{ft}^{3} / \mathrm{s}$ by Koslow and Van Haaften (1986) and $54,000 \mathrm{ft}^{3} / \mathrm{s}$ by Druffel and others (1979). Rathburn (1989 and 1991) estimated that a paleoflood discharge of Big Lost River in Box Canyon and overflow areas ranged from 2 to 4 million $\mathrm{ft}^{3} / \mathrm{s}$. She estimated that the depth of water at the Radioactive Waste Management Complex (RWMC) resulting from this large paleoflood was 50 to $60 \mathrm{ft}$.

Several regional analyses of flood magnitude and frequency in Idaho were used in this study (U.S. Army Corps of Engineers, 1967; Koslow, 1984; Koslow and Van Haaften, 1986; and Stone and others, 1993). Kjelstrom and Moffatt (1981) described a regional method of estimating flood magnitudes and frequencies by regression equations that used basin characteristics as independent variables. Quillian and Harenberg (1980) evaluated the stream-gaging network in Idaho and also developed regression equations for peak flows and average discharge. Harenberg (1980) presented regression equations that used channel geometry to estimate peak flows. In a study that included Arizona, Nevada, Utah, and parts of California, Colorado, Idaho, New Mexico, Oregon, Texas, and Wyoming, Blakemore and others (1994) developed regression equations that used drainage area and annual mean precipitation to estimate the magnitude and frequency of floods at ungaged sites.

\section{HISTORICAL AND RECORDED PEAK FLOWS}

Peak flows in the Big Lost River (tabulated in a report by Stone and others, 1993) occur mostly during May, June, and July because of melting snowpacks, often associated with rainstorms, in the mountains. Notable peak flows in the Big Lost River have been determined at several gaging stations. For example, the peak flow on June 12, 1965, in the Big Lost River at Howell Ranch, near Chilly, gaging station (13120500) was $3,450 \mathrm{ft}^{3} / \mathrm{s}$. On June 29,1965 , a peak flow of about $2,500 \mathrm{ft}^{3} / \mathrm{s}$ was estimated by indirect methods at the Arco gaging station, and a peak flow of about $2,220 \mathrm{ft}^{3} / \mathrm{s}$ was estimated at the INEL diversion dam (Barraclough and others, 1967). The different peak flow dates for the 1965 flood at the two gaging stations are probably due to the effects of reservoir storage, diversions for irrigation, channel-infiltration losses, and differences in the timing and location of rainstorms during the June 1229 period.

The highest recorded peak flow in the Big Lost River was $4,420 \mathrm{ft}^{3} / \mathrm{s}$ at the Howell Ranch gaging station on May 25, 1967. By June 22, when another peak occurred $\left(3,850 \mathrm{ft}^{3} / \mathrm{s}\right)$, Mackay Reservoir was nearly full and only a small attenuation of the second peak was recorded as it passed through the reservoir. Mean daily discharge was about $1,600 \mathrm{ft}^{3} / \mathrm{s}$ at the Howell Ranch gaging station from May through July, and the volume of flow was about 293,000 acre-ft. As a result of the long duration and high magnitude of streamflow upstream, the river overflowed its banks downstream from Mackay Reservoir and inundated about 7,000 acres; ground-water levels in the valley rose high enough to flood an additional 7,000 acres (U.S. Army Corps of Engineers, 1967). Flooding was caused by rapid snowmelt from above-normal air temperatures, several intense rainstorms interspersed throughout the period, and little reservoir storage capacity following an earlier peak on May 25. The recorded peak flow at the Arco gaging station was $1,890 \mathrm{ft}^{3} / \mathrm{s}$ on July 5, 1967.

Peak flows in Birch Creek (tabulated in a report by Stone and others, 1993) occur mostly during April, May, and June because of melting snowpacks in the mountains. Annual peaks were recorded at the Reno gaging station (13117000) in 1911-12, 1921-22, 1952-60, and 1962-63. This gaging station was discontinued in 1963. Two other gaging stations at Blue Dome Inn, near Reno (13117020), and at Eightmile 
Canyon Road, near Reno (13117030), were operated for part of the year (usually April through October) from 1967 to 1981 and 1985 to 1991, and from 1967 to 1981 and 1984 to 1988 , respectively. The highest recorded peak flow in Birch Creek was $220 \mathrm{ft}^{3} / \mathrm{s}$ at the Reno gaging station on April 1, 1962; larger peak flows may have occurred in other years when the station was not operated. The highest recorded peak flows at the Blue Dome Inn and Eightmile Canyon Road gaging stations were $149 \mathrm{ft}^{3} / \mathrm{s}$ on July 30,1969 , and $122 \mathrm{ft}^{3} / \mathrm{s}$ on April 18, 1984, respectively.

\section{ESTIMATION OF 100-YEAR PEAK FLOWS}

The 100-year peak flows for the Big Lost River and Birch Creek were estimated using flood-frequency curves and regression equations. Flood-frequency curves at gaging stations with at least 10 years of record generally provide reliable estimates of peak flow for recurrence intervals up to 100 years. The estimates are less reliable where the natural peak flows have been significantly altered because of storage and diversion structures.

Flood-frequency curves for all gaging stations were developed by fitting the array of recorded annual peak flows to a theoretical probability distribution. As recommended by the Interagency Advisory Committee on Water Data (1982), the three-parameter log-Pearson Type III distribution was used for this analysis. The three parameters that define the probability distribution and resultant flood-frequency curve at each station are the mean, standard deviation, and skew coefficient of the logs of annual peak flow. Because gaging-station values of skew coefficients are unreliable for shortterm records, the Interagency Advisory Committee on Water Data (1982) recommended that station skew coefficients be weighted with a generalized skew coefficient that is applicable to all sites in a region. A generalized skew coefficient of -0.3 , previously determined for the mountainous areas of the Big Lost River and Birch Creek Basins (Kjelstrom and Moffatt, 1981), was used for this study.

Flood-frequency information at gaging stations can be used to estimate flood frequency at ungaged sites by the development of regional regression equations based on climatic and basin characteristics. Regional floodfrequency equations are developed using ordinary and generalized least-squares multiple-regression analyses to relate peak flows for selected recurrence intervals (dependent variable) to selected climatic and basin characteristics (independent variables). Regional regression equations have been developed by several investigators to provide estimates of peak flows at ungaged sites. A channel geometry method (Harenberg, 1980) uses a regression equation that incorporates bankfull width as the independent variable to make estimates. The channel geometry method is applicable to alluvial stream channels and requires a visit to the stream. Estimates from channel geometry methods are based on the concept that the size and shape of an alluvial channel are a measure of the volume of water discharge and sediment transport. Quillian and Harenberg (1982) developed regression equations on the basis of only drainage area to estimate the 100 -year peak flow; Blakemore and others (1994) developed equations on the basis of both drainage area and mean annual precipitation as independent variables. Crosthwaite and others (1970) showed that mean altitude was related to annual mean flow from subbasins of the Big Lost River Basin. Kjelstrom and Moffatt (1981) noted that, in Idaho basins where 80 percent of the area was higher than $6,000 \mathrm{ft}$, peak flows resulted primarily from snowmelt.

The regional regression equations and procedures given by Kjelstrom and Moffatt (1981) were used in this report because the equations were based on different geographic regions and drainage area sizes and generalized skew coefficient maps developed for Idaho. The regression equations used three independent variables: drainage area, mean annual precipitation, and mean altitude.

Peak flow is poorly represented by regional regression equations for streams such as the Big Lost River and Birch Creek that flow over highly permeable rocks, in braided or small channels, or in large, hydraulically rough flood plains. Large amounts of streamflow can be lost by infiltration through permeable materials, and the magnitude of peak flow can be significantly reduced. Therefore, regional regression equations were used to calculate peak flow only for mountainous areas in the Big Lost River and Birch Creek Basins, and regression results were reduced to account for channelinfiltration losses. 


\section{Big Lost River}

Two methods were used to calculate the 100-year peak flow at the Big Lost River near Arco gaging station (13132500): (1) flood-frequency analysis for the Arco gaging station; and (2) the addition of results from flood-frequency analysis for the Big Lost River at Howell Ranch, near Chilly (13120500), and the Lower Cedar Creek above diversions, near Mackay (13128900), gaging stations to estimates from regression equations for ungaged tributaries.

Flood-frequency analysis resulted in a computed 100-year peak flow of $5,480 \mathrm{ft}^{3} / \mathrm{s}$ at the Arco gaging station. A peak flow of $2,500 \mathrm{ft}^{3} / \mathrm{s}$ in 1965 , which was estimated using indirect methods when the Arco gaging station was not operated, was included with the recorded annual peak flows at the station. The upper and lower 95-percent confidence limits for the estimated 100 -year peak flow were 11,600 and $3,150 \mathrm{ft}^{3} / \mathrm{s}$, respectively. This large difference between upper and lower limits was attributed to the damping of most peaks as a result of storage in Mackay Reservoir and low-lying areas in the valley and diversion of streamflow that does not return to the river. Previous estimates of the 100 -year peak flow were $4,480 \mathrm{ft}^{3} / \mathrm{s}$ (U.S. Army Corps of Engineers, 1991) and 3,700 $\mathrm{ft}^{3} / \mathrm{s}$ (Stone and others, 1993). Differences in the estimates are the result of using data from different periods of record, omission of the 1965 peak flow in the estimates by the U.S. Army Corps of Engineers (1991) and Stone and others (1993), and use of different skew coefficients.

Results from the flood-frequency analysis for the Arco gaging station were considered to show an unacceptably high level of uncertainty because of the wide range in confidence limits. Therefore, a second estimation method was employed, whereby results from the flood-frequency analysis for the Howell Ranch and Lower Cedar Creek gaging stations in subbasin 30 (fig. 2) were added to results from regional regression equations for 22 other subbasins in the basin and adjusted for channel-infiltration losses.

The Howell Ranch gaging station recorded 85 annual peaks through 1993. These peaks were not significantly affected by storage or diversions. Floodfrequency analysis resulted in a 100-year peak flow of $4,880 \mathrm{ft}^{3} / \mathrm{s}$ at the Howell Ranch gaging station and compared favorably with the highest recorded peak flow of $4,420 \mathrm{ft}^{3} / \mathrm{s}$ on May 25, 1967. The upper and lower 95-percent confidence limits were 5,660 and
$4,320 \mathrm{ft}^{3} / \mathrm{s}$, respectively, and indicated that the error of the estimated peak was considerably smaller than that of the estimated peak at the Arco gaging station. Previous estimates of the 100-year peak flow at the Howell Ranch gaging station were $4,800 \mathrm{ft}^{3} / \mathrm{s}$ (U.S. Army Corps of Engineers, 1991) and 4,690 $\mathrm{ft}^{3} / \mathrm{s}$ (Stone and others, 1993). These estimates are similar and differences are due to different periods of record used. Flood-frequency analysis for the Lower Cedar Creek gaging station (13128900), which had 15 years of streamflow data, resulted in an estimated 100 -year peak flow of $338 \mathrm{ft}^{3} / \mathrm{s}$ for subbasin 30 . The highest recorded peak flow of $310 \mathrm{ft}^{3} / \mathrm{s}$ for this station occurred on June 22, 1982.

Regional regression equations were used to estimate 100-year peak flows for the other 22 subbasins that drain mountainous and foothill areas downstream from the Howell Ranch gaging station (fig. 2). Subbasins on the valley floor were not considered to contribute peak flows to the Big Lost River and were not included in the regression analysis. Regional regression equations and procedures presented by Kjelstrom and Moffatt (1981) were used to estimate 100-year peak flows (table 1) for 22 subbasins shown in figure 2.

No adjustments to flood frequency or regression results were made for storage and diversion effects. Mackay Dam was assumed to be full, and fields were assumed to be completely saturated. These conditions existed during the 1967 floods (U.S. Army Corps of Engineers, 1991).

Large channel-infiltration losses were measured between the Howell Ranch gaging station and Mackay Reservoir (Crosthwaite and others, 1970, p. 46-47). Most of the losses occurred in a 5-mi reach known as Chilly Sinks (fig. 2), which is completely dry for about 8 months each year (Williams and Krupin, 1984, p. 36). Average measured losses in the Chilly Sinks reach were $120 \mathrm{ft}^{3} / \mathrm{s}$ and were greater than $1,000 \mathrm{ft}^{3} / \mathrm{s}$ after extended periods of dryness (Williams and Krupin, 1984, p. 36). A channel-infiltration rate for the Chilly Sinks reach of $3.4 \mathrm{in} / \mathrm{hr}$ was calculated to estimate losses for the 100-year peak flow by dividing representative reach loss by the product of reach length and width. First, average losses and losses after extended dry periods for the reach were averaged to produce a representative reach loss that could be expected through the duration of peak flow conditions soon after the dry period ended. Next, the peak flow of $4,420 \mathrm{ft}^{3} / \mathrm{s}$ on May 25, 1967, was used to calculate channel width with the following equation for stabilized flow in an al- 
luvial channel as described by Dawdy (1979):

$W=9.5 Q^{0.4}$, where $W$ is channel width (in feet) and $Q$ is flow in the channel (in cubic feet per second). The recurrence interval of that peak flow was 95 years. An estimated loss of $580 \mathrm{ft}^{3} / \mathrm{s}$ for a flow of $4,880 \mathrm{ft}^{3} / \mathrm{s}$ at the Howell Ranch gaging station (table 2) was calculated from the product of reach length, width, and channelinfiltration rate.

Infiltration rates for subbasin streams were estimated by adjusting the rate for the Chilly Sinks reach ( $3.4 \mathrm{in} / \mathrm{hr}$ ) according to the rock types underlying each stream (Crosthwaite and others, 1970, fig. 10). Miscellaneous discharge measurements, no-flow observations, and gaging-station records, primarily from 1967 , when the 95-year peak flow occurred at the Howell
Ranch gaging station, were used as a guide in making the adjustments. For example, channel-infiltration rates were decreased as low as $1.6 \mathrm{in} / \mathrm{hr}$ where the stream flowed over consolidated alluvium and were increased as high as $4.2 \mathrm{in} / \mathrm{hr}$ where the stream flowed over jointed carbonaceous rocks. For several subbasins, mainly on the eastern side of the valley, poorly developed channels in many of the steep canyons composed of carbonaceous rocks indicated that surface flows were rare. Adjustments to the channel-infiltration rate for these subbasins were made so that average flow from each subbasin would not reach the Big Lost River, but a small part of the 10-year peak flows would. For more developed channels composed of consolidated alluvium, or where flows had been measured, the infiltration

Table 1. Estimates of 100-year peak flow from subbasins of the Big Lost River between the Howell Ranch (13120500) and Arco (13132500) gaging stations

[mi ${ }^{2}$, square miles; in., inches; $\mathrm{ft}$, feet; in $/ \mathrm{hr}$, inches per hour; $\mathrm{ft} 3 / \mathrm{s}$, cubic feet per second; - , not applicable; locations of subbasins and gaging stations shown on figure 2; regression estimates obtained from equations in a report by Kjelstrom and Moffatt (1981)]

\begin{tabular}{|c|c|c|c|c|c|c|}
\hline \multirow[b]{2}{*}{$\begin{array}{c}\text { Subbasin } \\
\text { No. }{ }^{1}\end{array}$} & \multirow[b]{2}{*}{$\begin{array}{c}\text { Drainage } \\
\text { area }^{2} \\
\left(\mathrm{mi}^{2}\right)\end{array}$} & \multirow{2}{*}{$\begin{array}{c}\text { Mean } \\
\text { annual } \\
\text { precipitation }{ }^{2} \\
\text { (in.) }\end{array}$} & \multirow{2}{*}{$\begin{array}{c}\text { Mean } \\
\text { subbasin } \\
\text { altitude }^{2} \\
\text { (ft) }\end{array}$} & \multirow{2}{*}{$\begin{array}{l}\text { Infiltration } \\
\text { rate at } \\
\text { peak } \\
\text { (in/hr) }\end{array}$} & \multicolumn{2}{|c|}{ 100-year peak flows } \\
\hline & & & & & $\begin{array}{c}\text { Regression } \\
\text { estimate } \\
\left(\mathrm{ft}^{3} / \mathrm{s}\right)\end{array}$ & $\begin{array}{c}\text { After adjustments } \\
\text { for channel-infiltration } \\
\text { losses }\left(\mathrm{ft}^{3} / \mathrm{s}\right)\end{array}$ \\
\hline 9 & 50 & 14.1 & 7,380 & 2.9 & 704 & 250 \\
\hline 12 & 18 & 13.8 & 7,220 & 2.9 & 347 & 138 \\
\hline 19 & 2.6 & 30.7 & 9,860 & 3.2 & 101 & 30 \\
\hline 22 & 14 & 11.7 & 9,520 & 3.2 & 223 & 76 \\
\hline 23 & 9.9 & 13.3 & 9,060 & 3.2 & 192 & 65 \\
\hline 24 & 9.6 & 17.6 & 7,950 & 2.7 & 232 & 91 \\
\hline 25 & 12 & 11.9 & 7,000 & 3.1 & 251 & 101 \\
\hline 26 & 14 & 20.4 & 8,250 & 3.2 & 313 & 114 \\
\hline 33 & 16 & 22.9 & 8,410 & 4.1 & 356 & 106 \\
\hline 36 & 3.6 & 25.4 & 8,840 & 2.8 & 127 & 34 \\
\hline 37 & 28 & 21.9 & 8,230 & 2.9 & 519 & 188 \\
\hline 38 & 45 & 16.0 & 7,000 & 3.7 & 716 & 194 \\
\hline 39 & 93 & 27.5 & 7,960 & 1.6 & 1,370 & 541 \\
\hline 40 & 19 & 30.4 & 7,580 & 1.6 & 488 & 153 \\
\hline 41 & 33 & 20.8 & 7,850 & 1.6 & 595 & 196 \\
\hline 42 & 73 & 17.7 & 6,860 & 2.5 & 1,060 & 349 \\
\hline 43 & 22 & 17.0 & 6,900 & 3.7 & 451 & 76 \\
\hline Tota & eak flows fr & bbasins: & & & & 3,510 \\
\hline
\end{tabular}

\footnotetext{
'Subbasin numbers from Crosthwaite and others (1970).

${ }^{2}$ Basin characteristic values from Crosthwaite and others (1970).

${ }^{3}$ Value determined from flood-frequency analysis of data from the Lower Cedar Creek above diversions, near Mackay, gaging station (13128900).
} 
Table 2. Estimated peak flows at selected gaging stations and from contributing subbasins in the Big Lost River Basin and estimated channel-infiltration losses from the Big Lost River for selected recurrence intervals

[Locations of gaging stations, subbasins, and reaches shown on figure 2]

\begin{tabular}{|c|c|c|c|c|}
\hline \multirow{2}{*}{$\begin{array}{l}\text { Gaging stations, subbasins, } \\
\text { or location of losing reach }\end{array}$} & \multicolumn{4}{|c|}{$\begin{array}{l}\text { Peak flows at selected recurrence intervals } \\
\text { and concurrent channel-infiltration losses } \\
\text { (cubic feet per second) }\end{array}$} \\
\hline & 5-year & 10-year & 100-year & 500-year \\
\hline Big Lost River at Howell Ranch, near Chilly (13120500) ............ & 2,960 & 3,470 & 4,880 & 5,710 \\
\hline Contributing subbasins & 350 & 950 & 3,510 & 5,200 \\
\hline 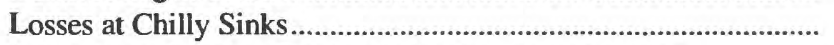 & 480 & 510 & 580 & 620 \\
\hline
\end{tabular}

'From table 1.

rate was adjusted so that a small part of the 5-year peak flow reached the river. Final channel-infiltration rates for the subbasin streams are shown in column 5 on table 1 .

Channel-infiltration losses for each subbasin were calculated by multiplying infiltration rate, stream distance, and channel width. The approximate stream distance from the mouth of the subbasin to the Big Lost River was estimated from 7.5-minute topographic maps, and channel width was calculated with the Dawdy equation. Although the assumption of stabilized flow does not apply to the tributaries and to the Big Lost River, the increase in channel depth and width between the 10- and 100-year peak flows at the Lower Cedar Creek gaging station is 0.35 and $5 \mathrm{ft}$, respectively; Dawdy's equation increases channel width by $10 \mathrm{ft}$. After subtraction of channel-infiltration losses, the resulting subbasin values for the 100 -year peak flows that reach the Big Lost River are shown in column 7 on table 1. Total peak flow from all subbasins was $3,510 \mathrm{ft}^{3} / \mathrm{s}$ (table 1).

Downstream from Mackay Reservoir, the Big Lost River is generally a losing stream, but along some reaches, the river gains water. Infiltration rates for the Big Lost River and diversion channels were based on measurements during 1966-68 (Crosthwaite and others, 1970) and 1985 (S.A. Goodell, U.S. Geological Survey, written commun., 1985). Measurements of flow in all channels every $3 \mathrm{mi}$ downstream in east-towest lines straight across the valley indicated an average infiltration rate of about $0.7 \mathrm{in} / \mathrm{hr}$. These measurements were made during the nonirrigation season when water was being released from the reservoir; the infil- tration rate may be greater or less during a flood in the valley. The lower infiltration rate of $0.7 \mathrm{in} / \mathrm{hr}$ in this reach, compared with the infiltration rate of $3.4 \mathrm{in} / \mathrm{hr}$ in the Chilly Sinks area, is attributed to finer grained deposits on the valley floor relative to the coarser deposits in the mountainous subbasins. Using Dawdy's equation $\left(W=9.5 Q^{0.4}\right)$, average channel width between Mackay Reservoir and the Arco gaging station was calculated to be about $350 \mathrm{ft}$ for the 100 -year peak flow.

In mapping the flood plain of the Big Lost River, the U.S. Army Corps of Engineer's (1991) delineation of the 100-year flood showed that the width ranged from about $200 \mathrm{ft}$ to more than $1,000 \mathrm{ft}$; therefore, an average width of $350 \mathrm{ft}$ probably is representative for the Big Lost River on the valley floor. Estimated channelinfiltration losses for the reach from Mackay Reservoir to the Arco gaging station were $550 \mathrm{ft}^{3} / \mathrm{s}$ for the 100 year peak flow (table 2). During high flow at the Arco gaging station in late June and early July of 1967, the average difference in the volume of streamflow released from the reservoir and measured at the Arco gaging station was about $700 \mathrm{ft}^{3} / \mathrm{s}$. However, irrigation diversions may account for some of the difference so that the $550-\mathrm{ft}^{3} / \mathrm{s}$ loss for the 100 -year peak flow seems reasonable and probably is somewhat conservative because of additional tributary flow. Thus, the calculated 100-year peak flow in the Big Lost River near the Arco gaging station was $7,260 \mathrm{ft}^{3} / \mathrm{s}$ (table 2). The method used to estimate the 100-year peak flow at the Arco gaging station also was used to estimate the 5-year, 10year, and 500-year peak flows (table 2).

The assumptions used to estimate the peak flows shown in table 2 were: (1) Mackay Reservoir was com- 
pletely full, and the flows were not affected by reservoir storage and regulation; (2) water was not diverted for irrigation; (3) flow in the Big Lost River occurred only in a single, unbraided channel; (4) peak flows from the Howell Ranch gaging station and subbasins arrived simultaneously at the Arco gaging station; (5) estimated infiltration losses were representative of losses along the channel during flooding; and (6) the peak flows were not attenuated. The assumption that Mackay Reservoir was full or nearly full was realized during 1965 and 1967 floods when the reservoir was nearly full. The assumption that peak flow arrived simultaneously at the Arco gaging station from the Howell Ranch gaging station and subbasins is also probably reasonable. In 1967, peak flows from the Lower Cedar Creek (13128900), Alder Creek (13129800), Antelope Creek (13130900), and Howell Ranch (13120500) gaging stations occurred within a 31.5 -hour period. The computer model CONROUT (Doyle and others, 1983) was used to simulate simultaneous hydrographs of peak flow for the four gaging stations. Model results showed that the simulated 100-year peak near Arco was about $200 \mathrm{ft}^{3} / \mathrm{s}$ less than the value shown in table 2 . The longest travel time of the peak, from the Howell Ranch gaging station to the Arco gaging station, was about 6 hours. Results from this simulation and the 1967 flood illustrate that peak flows are not significantly attenuated, travel times are relatively fast, and subbasin peaks occur within a relatively short period of time; thus, the assumption that subbasin peaks occurred simultaneously is probably reasonable.

To minimize effects of reservoir regulation inherent in flood-frequency analysis of the Arco gagingstation record, estimates of peak flow made from floodfrequency analyses for the two gaging stations upstream from Mackay Reservoir were added to estimates made from regional regression equations for intervening tributaries between the reservoir and the Arco gaging station. Although this method may have substantial error and produced an estimate of the 100-year peak flow that was 32 percent greater than the estimate made from flood-frequency analysis, the variable and generally indeterminate effects of reservoir regulation in the flow record for the Arco gaging station were eliminated.

\section{Routing Peak Flows in the Big Lost River Through Box Canyon}

A potential exists for the peak flow to be attenuated during travel through Box Canyon from the Big Lost River near Arco gaging station to the INEL boundary. Attenuation decreases the magnitude and lengthens the duration of a peak flow. The amount of attenuation that may occur through Box Canyon could have significant effects on the flood plain at the INEL. For example, if an earthen structure were designed for very attenuated flows but no attenuation occurred, earthen structures could fail or be eroded because of greater velocities and higher stages caused by larger peaks.

The computer model FOURPT (DeLong, 1993) was used to simulate streamflow conditions from the Arco gaging station to the INEL boundary. FOURPT is based on one-dimensional, partial-differential equations of continuity and momentum, which govern unsteady open-channel flow. For computational purposes, these equations are replaced by finite-difference equations, which approximate the actual solution and are solved by using a four-point-implicit method.

To demonstrate the effect of attenuation on peak flow in Box Canyon, the 100-year peak flow at the Arco gaging station was simulated. The channel length is about $7.5 \mathrm{mi}$, from the Arco gaging station to the INEL boundary. Channel geometry is regular and the cross-sectional area is rectangular. Rathburn (1989, p. 4) estimated average channel width and canyon depth to be about $125 \mathrm{ft}$ and $75 \mathrm{ft}$, respectively. Channel slope was estimated from 7.5-minute topographic maps to be about $17 \mathrm{ft} / \mathrm{mi}$.

Streambed materials in Box Canyon consist of coarse sand to gravel with cobbles and boulders composed mainly of basalt. The channel is sinuous and would contain the 100-year peak flow with no overbank flow. On the basis of a study by Rathburn (1989, p. 15), a value of Manning's $n$ of 0.050 was used for all cross sections through the canyon.

Two simulations were completed to illustrate the changes caused by attenuation as the peak flow traveled through Box Canyon. Both simulations used modifications of the 100-year flow hydrograph developed for the Arco gaging station and described in the section "Estimation of 100-Year Flow Volumes." For the first simulation, severai days around the maximum daily mean flow of the 100-year peak flow hydrograph and the 100-year peak flow (table 2) were used as the up- 
stream boundary condition to the FOURPT model. Attenuation of the peak flow, as shown in figure 4, was essentially nonexistent. For the second simulation, the hydrograph was shortened to a period of 2 hours, and all other parameters were held constant. The simulated peak flow was attenuated through Box Canyon (fig. 5) and was reduced by about $170 \mathrm{ft}^{3} / \mathrm{s}$ at the INEL boundary.

Results of these simulations illustrate that peak flows in Box Canyon were not significantly attenuated when the duration of the streamflow hydrograph is relatively long and were attenuated only slightly for a peak flow of short duration. If infiltration losses in Box Canyon are assumed to be balanced by possible local runoff from precipitation, peak flow at the INEL boundary can be considered the same as that at the Arco gaging station.

\section{Birch Creek}

Birch Creek at the INEL boundary and Birch Creek at the Birch Creek Sinks are ungaged sites. Peak flow data from the Birch Creek near Reno gaging station (13117000) are available for the upper part of Birch Creek Basin (subbasin 1, fig. 3). Flood-frequen- cy analysis of annual peak flows at the Reno gaging station determined that the 100-year peak flow was about $260 \mathrm{ft}^{3} / \mathrm{s}$ (Stone and others, 1993). This value is a poor representation of the 100 -year peak flow because no large peak flows were recorded and the period of record was short. The value of $260 \mathrm{ft}^{3} / \mathrm{s}$ probably is more representative of shorter (5- to 10-year) recurrence intervals.

Flow data for Birch Creek are available from two other gaging stations - Birch Creek at Blue Dome Inn, near Reno (13117020), and Eightmile Canyon Road, near Reno (13117030). The periods of record for these gaging stations are too short for reliable flood-frequency analysis.

Because the period of record of annual peak flows at gaging stations was not adequate to estimate the 100-year peak flow with flood-frequency analysis, regional regression equations were used to estimate 100 -year peak flows. The regional regression equations and procedures presented by Kjelstrom and Moffatt (1981) were used to estimate the 100-year peak flows (table 3) from the mountainous areas upstream from the Reno gaging station (subbasin 1) and for 18 other subbasins (fig. 3). Drainage areas east of the junction of the Blue Dome Inn gaging station and Highway 28 and at the southern end of the Lemhi Range were not included because their channels are not tributary to Birch

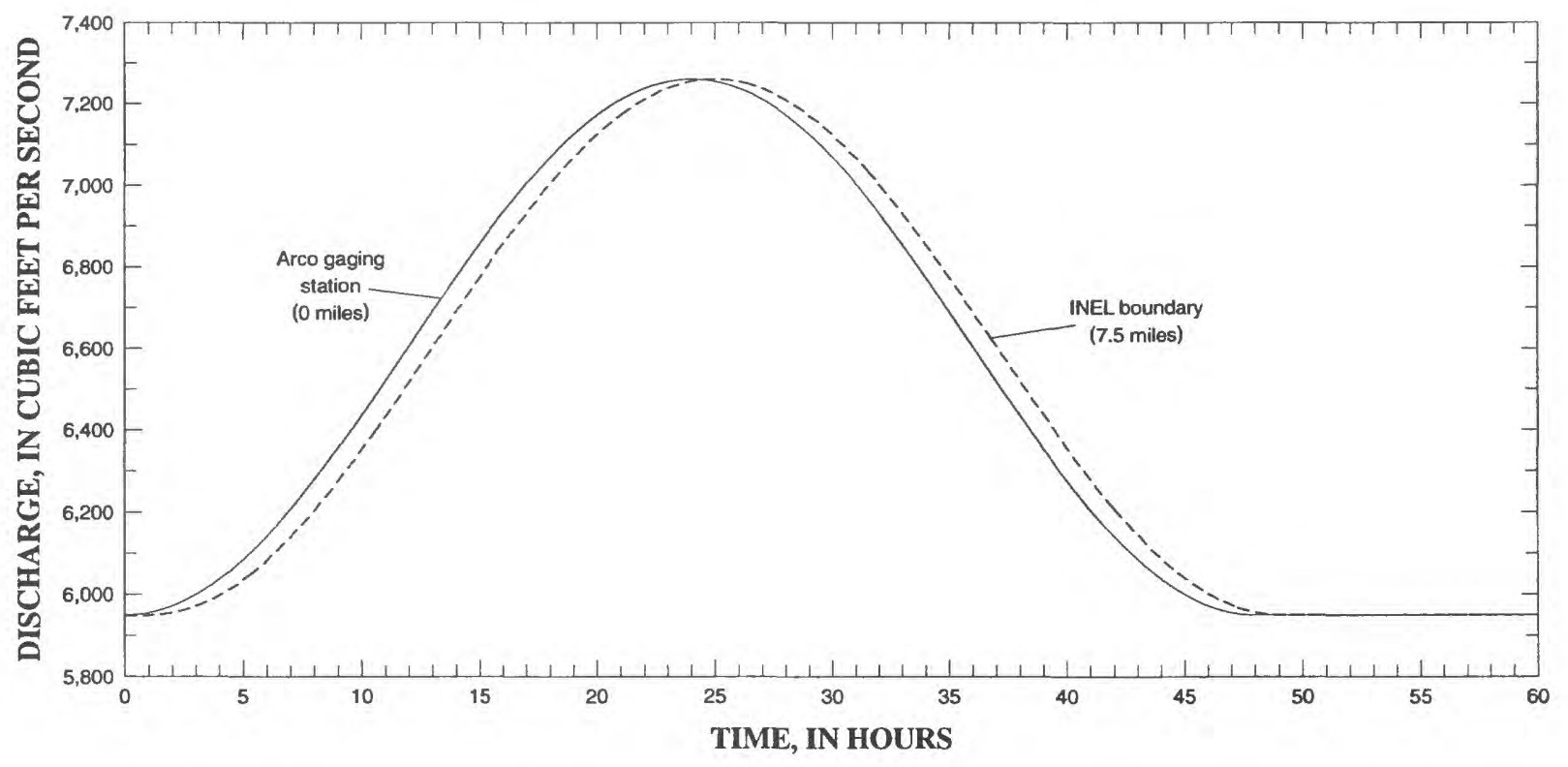

Figure 4. Simulated 48-hour streamflow hydrographs for a 100-year peak flow at the Arco gaging station routed through Box Canyon to the INEL boundary. (Locations shown on figure 1) 


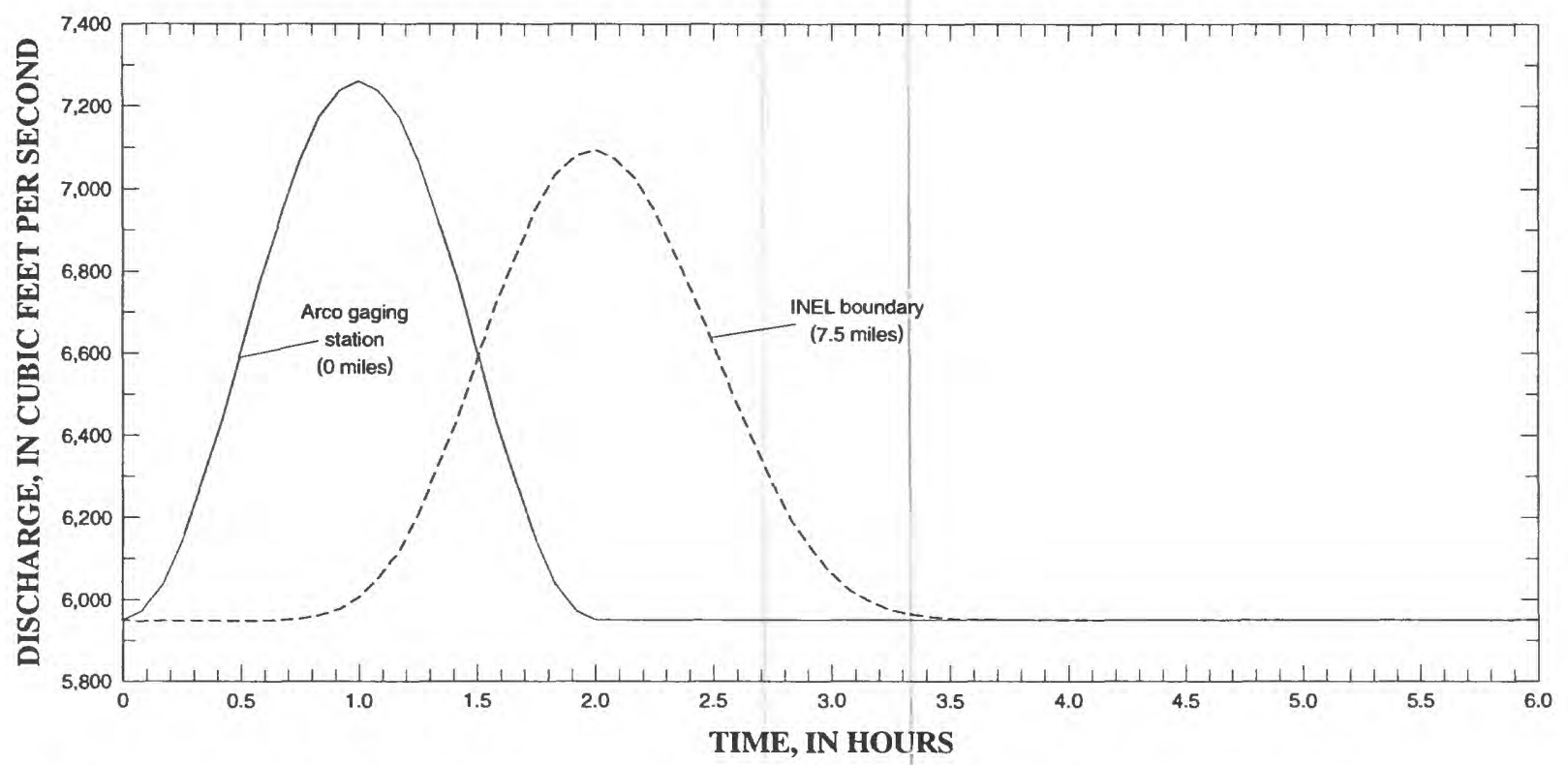

Figure 5. Simulated 2-hour streamflow hydrographs for a 100-year peak flow at the Arco gaging station routed through Box Canyon to the INEL boundary. (Locations shown on figure 1)

Creek; any ephemeral flow from these drainage areas flows directly onto the eastern Snake River Plain.

Channel-infiltration losses are included and estimated peak flows are reported in tables 3 and 4 . Channel-infiltration losses upstream from the Reno gaging station were determined by adjusting the infiltration rate until the 10 -year peak estimated from regression equations equaled the 10-year peak estimated from flood-frequency analysis of the gaging station data $\left(130 \mathrm{ft}^{3} / \mathrm{s}\right.$, table 4$)$. The resulting infiltration rate was $2.3 \mathrm{in} / \mathrm{hr}$. Infiltration rate, stream distance, and stream width were used to determine channel-infiltration losses as previously described for the Big Lost River, and the resulting losses were used to correct regression estimates of the 100- and 500-year peak flows at the Reno gaging station (table 4).

Estimation of the infiltration rate for channels from the 18 other subbasins tributary to Birch Creek was derived from two observations and one assumption: (1) Except for a few of the subbasins, channels are quite small or not discernible, and flow does not ordinarily reach Birch Creek; (2) flow at Birch Creek Sinks may occur at a 10-year recurrence interval, but not at a 5-year interval; and (3) some flow from most subbasins should reach Birch Creek during especially rare peak flows. An infiltration rate of $2.6 \mathrm{in} / \mathrm{hr}$ allows streamflow to reach Birch Creek from 16 of the 18 subbasins for a 500-year peak flow but allows no streamflow to reach the Birch Creek Sinks for a 5-year peak flow. The two subbasins that would not contribute flow to Birch Creek for the 500-year peak flow have small drainages and long channels, indicating limited runoff and large channel-infiltration losses.

Peak flows between the Reno gaging station and Birch Creek Sinks also were adjusted for channel-infiltration losses. From 1988 to 1994, 17 sets of gain-loss discharge measurements were made along Birch Creek from the Blue Dome Inn gaging station to Reno Ditch, about $10 \mathrm{mi}$ downstream. The average infiltration rate from these measurements was calculated to be about $1.4 \mathrm{in} / \mathrm{hr}$. Although infiltration rates in this reach were based on average conditions, they were considered to be comparable to rates during a 100 -year flood. Including peak flows from subbasins 1 through 6 and adjusting for channel-infiltration losses, the resulting 100year peak flow at the Blue Dome Inn gaging station was $980 \mathrm{ft}^{3} / \mathrm{s}$ (table 4). Including peak flows from subbasins 8 and 9 and adjusting for channel-infiltration losses, the resulting 100-year peak flow at the Reno Ditch diversion was $820 \mathrm{ft}^{3} / \mathrm{s}$ (table 4).

Peak flows also were adjusted for water being diverted to Reno Ditch. The maximum flow capacity for the Reno Ditch is $75 \mathrm{ft}^{3} / \mathrm{s}$ and, during flooding, flow in the ditch is assumed to be at maximum capacity. The 
Table 3. Estimates of 100-year peak flow from subbasins of Birch Creek between the Reno gaging station (13117000) and Birch Creek Sinks

$\left[\mathrm{mi}^{2}\right.$, square miles; in., inches; $\mathrm{ft}$, feet; $\mathrm{ft}^{3} / \mathrm{s}$, cubic feet per second; locations of subbasins shown on figure 3; regression estimates obtained from equations in a report by Kjelstrom and Moffatt (1981)]

\begin{tabular}{|c|c|c|c|c|c|}
\hline \multirow{2}{*}{$\begin{array}{c}\text { Birch } \\
\text { Creek } \\
\text { subbasin } \\
\text { No. }\end{array}$} & \multirow[b]{2}{*}{$\begin{array}{c}\text { Drainage } \\
\text { area } \\
\left(\mathrm{mi}^{2}\right)\end{array}$} & \multirow{2}{*}{$\begin{array}{c}\text { Mean } \\
\text { annual } \\
\text { precipitation } \\
\text { (in.) } \\
\end{array}$} & \multirow{2}{*}{$\begin{array}{l}\text { Mean } \\
\text { subbasin } \\
\text { altitude } \\
\text { (ft) }\end{array}$} & \multicolumn{2}{|c|}{ 100-year peak flows } \\
\hline & & & & $\begin{array}{c}\text { Regression } \\
\text { estimates } \\
\left(\mathrm{ft}^{3} / \mathrm{s}\right)\end{array}$ & $\begin{array}{c}\text { After adjustments } \\
\text { for channel-infiltration } \\
\text { losses }\left(\mathrm{ft}^{3} / \mathrm{s}\right)\end{array}$ \\
\hline 1 & & & & & 490 \\
\hline 2 & 6.91 & 17.1 & 6,800 & 204 & 116 \\
\hline 3 & 1.45 & 14.8 & 7,300 & 62 & 36 \\
\hline 4 & 6.40 & 16.1 & 7,800 & 171 & 136 \\
\hline 5 & 34.0 & 28.1 & 8,500 & 654 & 316 \\
\hline 6 & 2.16 & 24.9 & 7,600 & 98 & 6 \\
\hline 7 & 6.65 & 28.4 & 8,200 & 215 & 0 \\
\hline 8 & 1.41 & 27.3 & 8,100 & 72 & 10 \\
\hline 9 & .93 & 25.2 & 7,500 & 55 & 1 \\
\hline 10 & .93 & 25.8 & 8,000 & 53 & 1 \\
\hline 11 & 2.00 & 26.9 & 8,800 & 89 & 7 \\
\hline 12 & 1.07 & 23.0 & 7,800 & 54 & 0 \\
\hline 13 & 1.49 & 25.8 & 8,000 & 71 & 0 \\
\hline 14 & 3.70 & 24.0 & 8,500 & 130 & 36 \\
\hline 15 & 1.87 & 22.5 & 6,800 & 78 & 9 \\
\hline 16 & 3.47 & 22.5 & 8,000 & 121 & 0 \\
\hline 17 & 5.63 & 22.5 & 7,400 & 169 & 29 \\
\hline 18 & 2.62 & 18.2 & 6,200 & 91 & 12 \\
\hline 19 & 5.16 & 16.7 & 7,200 & 140 & 44 \\
\hline \multicolumn{5}{|c|}{ Total of peak flows from subbasins contributing to Birch Creek: } & 759 \\
\hline
\end{tabular}

resulting peak flow at the INEL boundary after adjusting for channel-infiltration losses and water diverted to Reno Ditch was $700 \mathrm{ft}^{3} / \mathrm{s}$ (table 4).

The 100-year peak flow in Birch Creek at the Reno Ditch diversion also was calculated using channel geometry methods (Harenberg, 1980) that require estimates of bankfull width. Using an average bankfull width of $38 \mathrm{ft}$, a 100 -year peak flow of $1,120 \mathrm{ft}^{3} / \mathrm{s}$ was calculated. Although this value is greater than the estimate of $895 \mathrm{ft}^{3} / \mathrm{s}\left(820 \mathrm{ft}^{3} / \mathrm{s}\right.$ shown in table 4 plus the $75 \mathrm{ft}^{3} / \mathrm{s}$ diverted into the ditch), the difference can be attributed to overestimating bankfull width and to regression errors.

Subbasins 10 through 19 can contribute flow to Birch Creek between the INEL boundary to the terminus of Birch Creek at Birch Creek Sinks. The infiltration rate of $1.4 \mathrm{in} / \mathrm{hr}$ used for the upper reaches of Birch Creek also was used to calculate channel-infiltration losses for this reach. The resulting peak flow at Birch Creek Sinks was $590 \mathrm{ft}^{3} / \mathrm{s}$ (table 4).

Peak flows in Birch Creek estimated at Birch Creek Sinks likely would be reduced considerably be- cause of water ponding north of Highway 22 and the routing of water through constructed channels and gravel pits south of Highway 22. Peak flows shown in table 4 were not adjusted to account for these conditions.

The 5-, 10-, and 500-year peak flows (table 4) were estimated with the same method used to estimate the 100 -year peak flow. Stream and channel lengths and infiltration rates were constant for calculation of all peak flows, but channel width for each peak flow was calculated using Dawdy's equation.

The assumptions used to estimate the peak flows shown in table 4 were: (1) Water was not diverted for irrigation; (2) $75 \mathrm{ft}^{3} / \mathrm{s}$ was diverted to the Reno Ditch; (3) flow in Birch Creek occurred only in a single, unbraided channel; (4) peak flow from the Reno gaging station and subbasins arrived simultaneously at the Blue Dome Inn gaging station, Reno Ditch diversion, INEL boundary, and Birch Creek Sinks, respectively; (5) estimated infiltration losses were representative of losses along the channel during flooding; (6) the peak flows were not attenuated; and (7) Highway 22 and 
Table 4. Estimated peak flows at gaging stations and other selected sites in the Birch Creek Basin at selected recurrence intervals

[Locations of gaging stations and sites shown on figure 3; peak flows include adjustments for channel-infiltration losses]

\begin{tabular}{|c|c|c|c|c|}
\hline $\begin{array}{l}\text { Gaging stations and } \\
\text { other selected sites } \\
\text { on Birch Creek }\end{array}$ & \multicolumn{4}{|c|}{$\begin{array}{l}\text { Peak flows at selected recurrence intervals } \\
\text { (cubic feet per second) }\end{array}$} \\
\hline Reno gaging station (13117000) & 110 & 130 & 490 & 740 \\
\hline Blue Dome Inn gaging station (13117020) & 240 & 370 & 980 & 1,570 \\
\hline 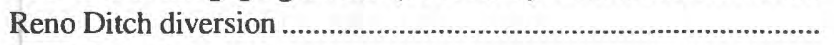 & 150 & 260 & 820 & 1,380 \\
\hline INEL boundary & 55 & 150 & 700 & 1,240 \\
\hline
\end{tabular}

constructed channels and gravel pits south of Highway 22 did not affect peak flows.

\section{ESTIMATION OF 100-YEAR FLOW VOLUMES}

The volume of runoff can be determined by computing the area under a streamflow hydrograph for a particular length of time. For the Big Lost River and Birch Creek, a length of 60 days was used because this period approximates the length of floods that were recorded in 1965 and 1967 at the Big Lost River at Howell Ranch gaging station. Daily mean flow from these floods was greater than $1,000 \mathrm{ft}^{3} / \mathrm{s}$ from May 16 through July 22, 1965 (68 days), and from May 19 through July 19, 1967 (62 days). Any flows outside the 60 -day period likely would be diminished by storage and diversions. Peak flow within the 60 -day period was selected to be on the 24th day, on the basis of the 1965 flood in the Big Lost River. The assumptions used to estimate peak flows in the Big Lost River and Birch Creek also were used to estimate the 100-year flow volumes. Two additional assumptions were that (1) for the Big Lost River, the 100-year flow volumes described by hydrographs for the Howell Ranch gaging station and subbasins in the Big Lost River Basin arrived simultaneously at the Arco gaging station; and (2) for Birch Creek, the 100-year flow volumes described by hydrographs for the Reno gaging station and subbasins arrived simultaneously at the Blue Dome Inn gaging station, Reno Ditch diversion, INEL boundary, and Birch Creek Sinks, respectively. These assumptions would produce the largest possible flow-volume estimates for this method.
In this report, 100-year flow hydrographs for 60 -day periods at selected gaging stations were developed using the following steps:

1. The 1-day 100-year mean flow, obtained from published high-flow analysis of gaging-station data, was assigned for the daily mean flow $(q)$ on the 24th day of the hydrograph on the basis of the 1965 flood.

2. The primary unit flow $\left(Q^{\prime}\right)$ was computed by dividing the 1-day 100 -year mean flow by 60 , which is the duration, in days, of a typical peak flow hydrograph for the Big Lost River.

3. The ascending and descending limbs of the hydrograph were derived from published annual maximum D-day mean flows having a 100 -year recurrence interval for $\mathrm{D}$-days of $1,3,7,15,30$, and 60 . For instance, the 30-day 100 -year mean flow encompassed a 30 -day period that began somewhere on the ascending limb and ended somewhere on the descending limb. The hydrograph was skewed to the right, as indicated by the peak occurring on day 24 ( 40 percent of the 60 -day duration), rather than on day 30 (50 percent of the 60-day duration). Therefore, using the 30-day flow as an example, the first day of the 30-day period began on the ascending limb, approximately 12 days ( 40 percent) prior to day 24. The last day of the 30-day period ended on the descending limb, approximately 18 days (60 percent) after day 24 . This approach was repeated for the 3,7 , and $15 \mathrm{D}$-day 100 -year mean flows.

4. Each published D-day 100-year mean flow was divided by the primary unit flow $(Q)$ to obtain an associated initial unit-flow coefficient $(n)$. 
The initial coefficients were adjusted for days 1 through 23 and 25 through 60 in an iterative manner until the published maximum D-day 100-year mean flows were approximated and a smooth transition in daily mean flow from one day to the next was obtained. For example, the initial unit-flow coefficient of 54.8 for the 7 -day 100 -year mean flow of $4,250 \mathrm{ft}^{3} / \mathrm{s}$ at the Big Lost River at Howell Ranch, near Chilly (table 5) was adjusted for days 22 through 28 so that the 100-year mean flows for 3 and 7 days were approximated and the ascent to and descent from the 1-day peak flow on day 24 were smooth. This iterative approach was repeated for the 3,15,30, and $60 \mathrm{D}$-day 100-year mean flows.

5. Estimated daily mean flows $(q)$ were calculated by multiplying the unit-flow coefficient $(n)$ by the primary unit flow $\left(Q^{\prime}\right)$.

For ungaged sites, the 100-year flow hydrographs for 60 -day periods were developed using the following steps:

1. A gaging-station flow hydrograph that likely represented the ungaged site was selected, or a composite of several gaging-station hydrographs in the region was used.

2. The 1-day mean flow $(q)$ at the ungaged site was determined by multiplying the 100 -year peak flow at the ungaged site (tables 1 and 3 ) by the ratio of the 1-day mean flow and peak flow at the representative gaging station.

3. The primary unit flow $(Q)$ was computed by dividing the 1-day mean flow by 60 .

4. The unit-flow coefficients $(n)$ at the representative gaging station for the other 59 days were used to determine the daily mean flow $(q)$ at the ungaged site.

\section{Big Lost River}

Representative hydrographs developed for the Howell Ranch and Lower Cedar Creek gaging stations (table 5) were used to develop 100-year flow hydrographs for 60 days for the upper Big Lost River Basin because flows for the Arco gaging station were affected by upstream storage and diversions.
Mean flows at the Howell Ranch gaging station for $1,3,7,15,30$, and 60 consecutive days were 4,650 , $4,520,4,250,3,840,3,230$, and $2,640 \mathrm{ft}^{3} / \mathrm{s}$, respective$1 y$, for a 100-year recurrence interval (Stone and others, 1993, p. 24). The hydrograph for the Howell Ranch gaging station was used to determine a 60 -day flow volume of 310,000 acre-ft (table 5).

The 60-day representative hydrograph developed from the data for the Lower Cedar Creek gaging station (Stone and others, 1993, p. 28) was used to make representative hydrographs for all 23 contributing subbasins (table 5). Consequently, the unit-flow coefficient $(n)$ for Lower Cedar Creek was multiplied by the primary unit flow $(Q)$ for the 23 subbasins to obtain daily mean flow $(q)$. The primary unit flow for the subbasins was determined by multiplying the ratio of the 1-day mean and peak flows from Lower Cedar Creek (0.84) by the peak flow from each subbasin that reaches the river and dividing the result by 60 . The estimated 60 -day flow volume from the 23 contributing subbasins was 165,000 acre-ft (table 5).

Flow volumes for a 60-day hydrograph for the Arco gaging station (table 5) were determined by adding the mean daily flows $(q)$ at the Howell Ranch gaging station and the total from the 24 subbasins and subtracting calculated channel-infiltration losses. Channelinfiltration losses were calculated using the same infiltration rates and distances used in the calculation of peak flow. Average channel width changed according to the flow for each day. The estimated total volume of flow at the Arco gaging station for 60 days was 390,000 acre-ft (table 5).

\section{Birch Creek}

Peak flows that reach Birch Creek Sinks could overflow playas shared with the Big Lost River and threaten facilities downstream. No representative hydrograph was developed for the Reno gaging station because the record was short and no data were available during years when flooding occurred in the Big Lost River. Because hydrologic and hydraulic conditions in Medicine Lodge Creek Basin (fig. 1) are similar to those in the Birch Creek Basin, a 60-day representative hydrograph developed for Medicine Lodge Creek at Ellis Ranch, near Argora (13116000), was used to determine flow volumes at sites in the Birch Creek Basin. 
Table 5. Values for 60-day flow hydrographs and daily estimates of 100-year peak flow volumes at selected gaging stations and from contributing subbasins in the Big Lost River Basin

[ $n$, unit-flow coefficients applied to day; $Q^{\prime}$, primary unit flow, which is the 100-year daily mean flow, in cubic feet per second, divided by $60 ; q$, daily mean flow, in cubic feet per second; contributing subbasins are listed in table 1; locations of gaging stations and subbasins shown on figure 2]

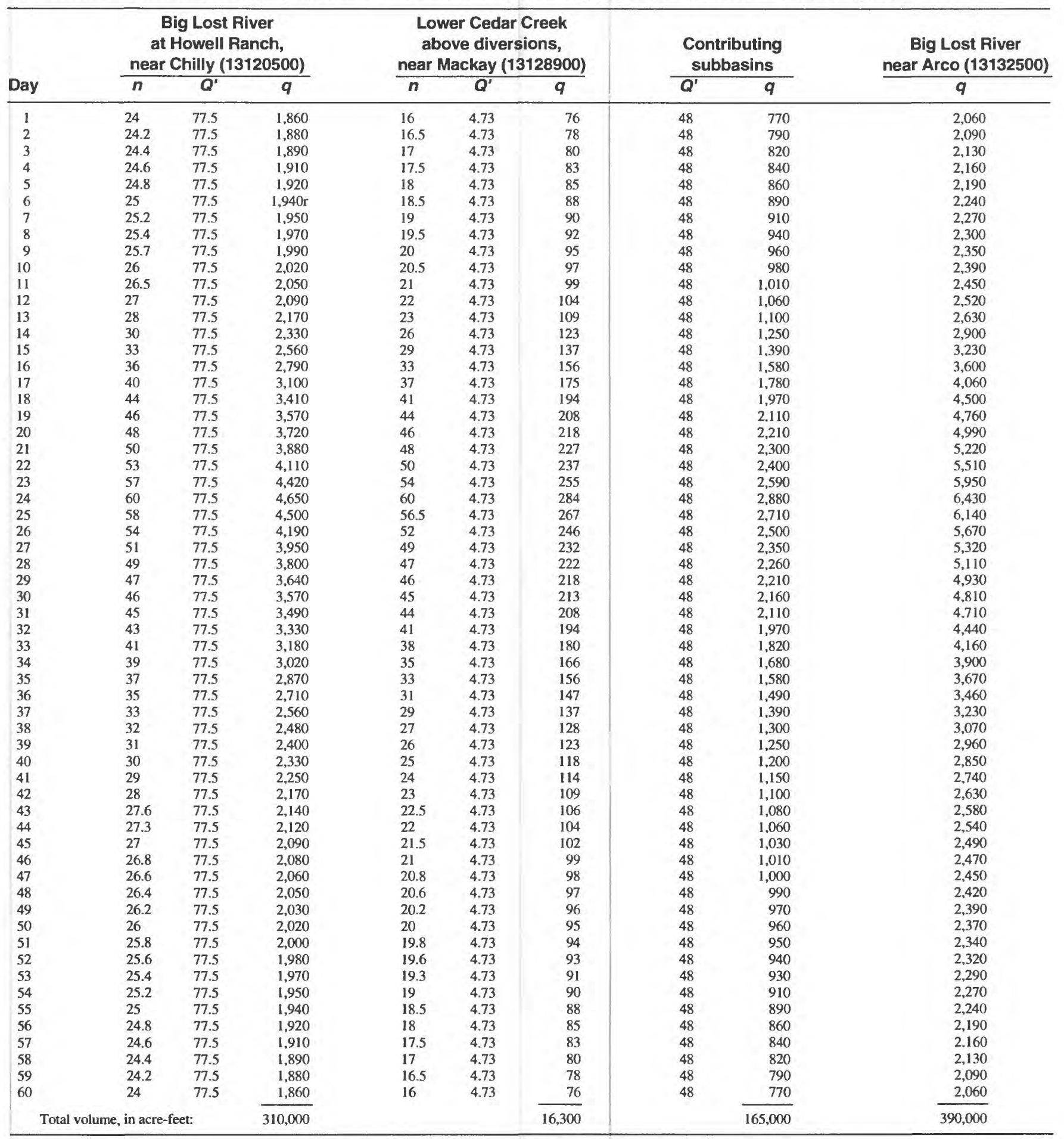


Table 6. Values for 60-day flow hydrographs and daily estimates of 100-year peak flow volumes at the Medicine Lodge Creek at Ellis Ranch, near Argora, gaging station and at selected gaging stations and sites in the Birch Creek Basin

$\left[n\right.$, unit-flow coefficients applied to day; $Q^{\prime}$, primary unit flow, which is the 100-year daily mean flow, in cubic feet per second, divided by $60 ; q$, daily mean flow, in cubic feet per second; locations of gaging stations and sites shown on figures 1 and 3]

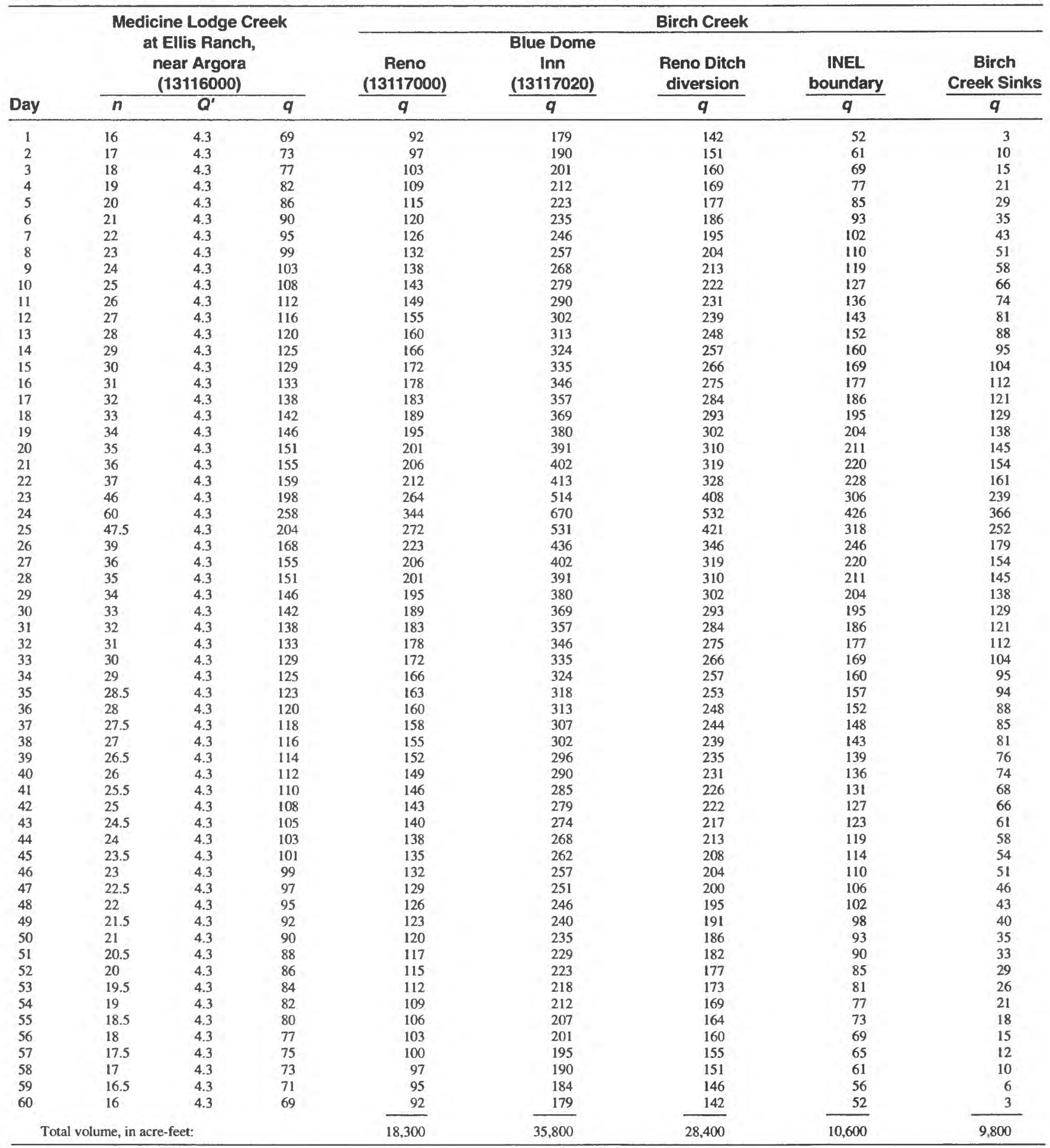


The same procedure that was used to estimate the 100-year peak flow at gaging stations was used to develop the 60-day representative hydrograph for the Medicine Lodge Creek at Ellis Ranch gaging station. The magnitude and frequency of annual peak flows were based on 28 years of record from 1942 to 1969. Mean annual flows for periods of $1,3,7,15,30$, and 60 consecutive days for the 100 -year recurrence interval were $258,220,181,165,139$, and $116 \mathrm{ft}^{3} / \mathrm{s}$, respectively (Kjelstrom and others, 1996, p. 258). The primary unit flow $(Q)$ was $4.3 \mathrm{ft}^{3} / \mathrm{s}$. The peak flow again was selected to be on the 24th day. Results of calculations are shown in columns 1 through 4 on table 6 .

The unit-flow coefficient developed for the Medicine Lodge Creek at Ellis Ranch gaging station (column 2 on table 6) was used for the Reno gaging station and subbasins (2-22) contributing flow to Birch Creek. Unit-flow coefficients were determined using the ratio $(0.70)$ of the 1-day mean flow and peak flow for the 100-year recurrence interval of the Medicine Lodge Creek at Ellis Ranch gaging station. This ratio was multiplied by the 100-year peak flows (table 4) to determine the 1-day mean flow at the Reno gaging station and from subbasins. Channel-infiltration losses were adjusted daily on the basis of the daily mean flows for the sites on Birch Creek shown in table 4. Infiltration losses were estimated in a manner similar to estimation of losses for peak flow. Distances between these sites and the infiltration rate of $1.4 \mathrm{in} / \mathrm{hr}$ were held constant. Average channel width changed according to the flow in the reach for each day. Hydrograph data estimated for the Reno gaging station, Blue Dome Inn gaging station, Reno Ditch diversion, INEL boundary, and Birch Creek Sinks are shown in table 6.

The hydrograph data for the INEL boundary and Birch Creek Sinks were determined by adjusting the daily mean flows at the Reno Ditch for diversions, channel-infiltration losses, and inflow from subbasins (10-22). Flow to the Reno Ditch was assumed to be $75 \mathrm{ft}^{3} / \mathrm{s}$ for the 60 -day period. The 100 -year volume of flow entering the INEL area was estimated to be 10,600 acre- $\mathrm{ft}$ (table 6). The 100-year volume of flow to the Birch Creek Sinks was estimated to be about 9,800 acre-ft (table 6). Flow to the Birch Creek Sinks, however, would decrease because of storage and infiltration losses in gravel pits and diversion channels.

Koslow (1984) estimated that the diking system in the Birch Creek Playa can contain 13,000 acre-ft; thus, the 100-year flow volume from Birch Creek is not significant unless the Birch Creek Playa receives water from other sources, such as the Big Lost River or from melting snowpacks combined with rainfall on frozen ground (Koslow, 1984). Water available for runoff from snowmelt and precipitation in the eastern Snake River Plain in Idaho for 4- to 15-days' duration for a 100 -year recurrence interval was estimated to be 5 and 8 in., respectively (Frederick and Tracey, 1976, p. 25, 29). For the approximately $20 \mathrm{mi}^{2}$ that likely would contribute water to the Birch Creek Playa under these conditions, the volume in the first 4 and 15 days would be 5,300 and 8,500 acre-ft, respectively. Consequently, the 100-year localized flood solely from snowmelt combined with rainfall and frozen ground would be contained by the present diking system in the Birch Creek Playa. However, combination of the 100-year volume of flow from Birch Creek to the Birch Creek Sinks with either the 4- or 15-day localized runoff would exceed the capacity of the diking system.

\section{SUMMARY}

Peak flows and flow volumes with recurrence intervals of 100 years for the Big Lost River and Birch Creek were estimated so the extent of the 100-year flood plain at the Idaho National Engineering Laboratory (INEL) could be delineated. Future studies should be able to use models to route peak flows through the INEL area to spreading areas and playas. This report quantifies peak flows and flow volumes that will be used in future modeling studies to delineate the flood plain.

The Big Lost River is the most likely source of flooding at the INEL. Annual peak flows at the Big Lost River near Arco gaging station are affected by reservoir ștorage and diversion to irrigation canals. As a result, flood-frequency analysis of data at the Arco gaging station probably does not represent the range of natural flow variability, and other methods were used. Flood-frequency analyses at two upstream gaging stations in the Big Lost River Basin were combined with regional regression equations to estimate peak flows and flow volumes at the Arco gaging station.

Estimates of peak flows were obtained by a floodfrequency analysis of 85 annual peaks in the Big Lost River at Howell Ranch gaging station. The $450-\mathrm{mi}^{2}$ drainage area upstream from this gaging station produced an estimated peak flow of $4,880 \mathrm{ft}^{3} / \mathrm{s}$ for a recurrence interval of 100 years. The highest recorded peak 
was $4,420 \mathrm{ft}^{3} / \mathrm{s}$ on May 25,1967 . Because flooding in the Big Lost River is caused primarily by snowmelt in mountainous areas, only mountainous areas between the Howell Ranch and Arco gaging stations would likely contribute runoff. On the basis of that assumption, 23 subbasins were selected, one of which (Lower Cedar Creek) has a gaging-station record of 15 years. Flood-frequency analysis of annual peaks at the Lower Cedar Creek gaging station and regional regression equations at the other 22 subbasins produced estimates of peak flows with a recurrence interval of 100 years. Because infiltration losses in the river channel and on the alluvial fans between the subbasins and the river are large, channel-infiltration losses were subtracted from peak flows.

Channel-infiltration losses in the Big Lost River were determined by discharge measurements and gaging-station records upstream and downstream from losing reaches. Infiltration rates were estimated by calculating the water-surface area between upstream and downstream measuring sites by using approximate channel distances and average widths. In Chilly Sinks between the Howell Ranch gaging station and Mackay Reservoir, the infiltration rate was $3.4 \mathrm{in} / \mathrm{hr}$; between Mackay Reservoir and the Arco gaging station, the infiltration rate was $0.7 \mathrm{in} / \mathrm{hr}$. Estimates of infiltration rates in channels from the subbasins to the river ranged from 1.6 to $4.2 \mathrm{in} / \mathrm{hr}$. Estimates were based on rock type and observations of no flow and discharge measurements in 1967.

The estimated 100-year peak flow in the Big Lost River near the Arco gaging station was $7,260 \mathrm{ft}^{3} / \mathrm{s}$. The primary assumptions used to estimate this peak were:

(1) The peak flow was not affected by storage in Mackay Reservoir, (2) water was not diverted to irrigation canals, (3) peak flows from different parts of the basin arrived simultaneously at the Arco gaging station, (4) infiltration losses were representative during flooding, and (5) the peak flow was not attenuated.

The computer model FOURPT was used to simulate streamflow from the Big Lost River near Arco gaging station to the INEL boundary. This is a 7.5-mi reach through a steep-walled canyon about $75 \mathrm{ft}$ deep and $125 \mathrm{ft}$ wide. Model simulations indicated that peak flows were not significantly attenuated. Thus, peak flow determined at the INEL boundary is assumed to be the same as that at the Arco gaging station.

Because gaging-station records of Birch Creek were not adequate to estimate the 100-year peak flow, flow estimates were made using regional regression equations. These estimates were adjusted for channelinfiltration losses. Flooding in Birch Creek is caused primarily by snowmelt in mountainous areas. The 100-year peak flow in Birch Creek at the Reno gaging station was estimated to be $490 \mathrm{ft}^{3} / \mathrm{s}$. Downstream from the Reno gaging station, 18 mountainous subbasins were selected as likely contributors to the 100 - and 500-year peak flows in Birch Creek. Only 8 of the 18 subbasins had simulated peak flows that reached Birch Creek for the 100-year flood because of channel-infiltration losses.

Before Birch Creek reaches the INEL boundary, up to $75 \mathrm{ft}^{3} / \mathrm{s}$ is diverted to Reno Ditch, which supplies a power-generation plant several miles east of Birch Creek. After accounting for diversion, channel infiltration, and inflow from subbasins, the 100-year peak flow at the INEL boundary was estimated to be about $700 \mathrm{ft}^{3} / \mathrm{s}$ and, at Birch Creek Sinks, to be about $590 \mathrm{ft}^{3} / \mathrm{s}$. The primary assumptions used to estimate these peaks were: (1) The Reno Ditch diverted $75 \mathrm{ft}^{3} / \mathrm{s}$, (2) peak flows from different parts of the basin arrived simultaneously, (3) channel-infiltration losses were representative of losses during flooding, and (4) the peak flow was not attenuated.

Flow volumes from the Big Lost River and Birch Creek also were determined so the extent of the flood plain could be delineated. Representative hydrographs at selected gaging stations were developed for 60-day periods. Hydrographs were developed by creating smooth curves that contain the computed mean flow volumes having a recurrence interval of 100 years for 1-, 3-, 7-, 15-, 30-, and 60-day periods. Records of the Big Lost River at Howell Ranch gaging station were used to provide a representative hydrograph for that part of the Big Lost River Basin, and records of the Lower Cedar Creek gaging station were used to provide a representative hydrograph for the contributing subbasins downstream from the Howell Ranch gaging station. Because gaging stations in the Birch Creek Basin did not have sufficient record, a gaging-station record of Medicine Lodge Creek at Ellis Ranch, which drains a basin hydrologically similar to that of Birch Creek, was used to develop a representative hydrograph. The volume of flow entering the INEL area from the Big Lost River during a 60-day period was 390,000 acre-ft and, from Birch Creek, was about 10,600 acre-ft. However, flow from Birch Creek reaching the Birch Creek Playa probably would be reduced because of channel-infiltration losses. The Birch Creek 
Playa probably could receive flood water from the Big Lost River and from localized floods.

\section{REFERENCES CITED}

Barraclough, J.T., Teasdale, W.E., and Jensen, R.G., 1967, Hydrology of the National Reactor Testing Station, Idaho, 1965: U.S. Geological Survey Open-File Report, 107 p.

Bennett, C.M., 1986, Capacity of the diversion channel below the flood-control dam on the Big Lost River at the Idaho National Engineering Laboratory, Idaho: U.S. Geological Survey Water-Resources Investigations Report 86-4204, 25 p.

-1990, Streamflow losses and ground-water level changes along the Big Lost River at the Idaho National Engineering Laboratory, Idaho: U.S. Geological Survey Water-Resources Investigations Report 90-4067, 49 p.

Blakemore, E.T., Hjalmarson, H.W., and Waltemeyer, S.D., 1994, Methods for estimating magnitude and frequency of floods in the southwestern United States: U.S. Geological Survey Open-File Report 93-419, $211 \mathrm{p}$.

Carrigan, P.H., Jr., 1972, Probability of exceeding capacity of flood-control system at the National Reactor Testing Station, Idaho: U.S. Geological Survey Open-File Report, 102 p.

Crosthwaite, E.G., Thomas, C.A., and Dyer, K.L., 1970, Water resources in the Big Lost River Basin, south-central Idaho: U.S. Geological Survey OpenFile Report, 109 p.

Dawdy, D.R., 1979, Flood frequency estimates on alluvial fans: American Society of Civil Engineers, Journal of the Hydraulics Division, v. 105, no. HY11, p. 1407-1413.

DeLong, L.L., 1993, A numerical model for learning concepts of streamflow simulation, in Shen, Hsieh Wen, Su, S.T., and Wen, Feng, eds., Hydraulic Engineering '93, vol. 2, San Francisco, Calif., 1993, Proceedings: New York, American Society of Civil Engineers, p. 1586-1591.

Doyle, J.H., Jr., Shearman, J.O., Stiltner, G.J., and Krug, W.R., 1983, A digital model for streamflow routing by convolution methods: U.S. Geological Survey Water-Resources Investigations Report 83-4160, $130 \mathrm{p}$.

Druffel, Leroy, Stiltner, G.J., and Keefer, T.N., 1979, Probable hydrologic effects of a hypothetical failure of Mackay Dam in the Big Lost River Valley from Mackay, Idaho, to the Idaho National Engineering Laboratory: U.S. Geological Survey Water-Resources Investigations Report 79-99, 47 p.

Frederick, R.H., and Tracey, R.J., 1976, Water available for runoff for 4 to 15 days duration in the Snake River Basin in Idaho: Silver Spring, Md., National Oceanic and Atmospheric Administration, NOAA Technical Memorandum NWS HYDRO-29, 39 p.

Harenberg, W.A., 1980, Using channel geometry to estimate flood flows at ungaged sites in Idaho: U.S. Geological Survey Water-Resources Investigations Report 80-32, 39 p.

Interagency Advisory Committee on Water Data, 1982, Guidelines for determining flood flow frequency, Bulletin 17B of the Hydrology Subcommittee: Reston, Va., U.S. Geological Survey, Office of Water Data Coordination, [183 p.].

Kjelstrom, L.C., 1986, Flow characteristics of the Snake River and water budget for the Snake River Plain, Idaho and eastern Oregon: U.S. Geological Survey Hydrologic Investigations Atlas HA-680, scale $1: 1,000,000,2$ sheets.

Kjelstrom, L.C., and Moffatt, R.L., 1981, A method of estimating flood-frequency parameters for streams in Idaho: U.S. Geological Survey Open-File Report 81-909, $99 \mathrm{p}$.

Kjelstrom, L.C., Stone, M.A.J., and Harenberg, W.A., 1996, Statistical summaries of streamflow data for selected gaging stations in Idaho and adjacent States through September 1990, Volume 1, Gaging stations with 10 or more years of record: U.S. Geological Survey Water-Resources Investigations Report 94-4069, 533 p.

Koslow, K.N., 1984, Hydrological characterization of Birch Creek Basin: Idaho Falls, Idaho, EG\&G Idaho, Inc., EGG-PBS-6782, 30 p.

Koslow, K.N., and Van Haaften, D.H., 1986, Flood routing analysis for a failure of Mackay Dam: Idaho Falls, Idaho, EG\&G Idaho, Inc., EGG-EP-7184, 33 p.

Lamke, R.D., 1969, Stage-discharge relations on Big Lost River within National Reactor Testing Station, Idaho: U.S. Geological Survey Open-File Report, 29 p.

Mundorff, M.J., Crosthwaite, E.G., and Kilburn, Chabot, 1964, Ground water for irrigation in the Snake River basin in Idaho: U.S. Geological Survey Water-Supply Paper 1654, 224 p. 
Noble, C., 1980, A two-dimensional analysis of flooding of the Big Lost River below Box Canyon Outlet: Idaho Falls, Idaho, EG\&G Idaho, Inc., EGG-EI-80-2, [26 p.]

Quillian, E.W., and Harenberg, W.A., 1982, An evaluation of Idaho stream-gaging networks: U.S. Geological Survey Open-File Report 82-865, 57 p.

Rathburn, S.L., 1989, Pleistocene glacial outburst flooding along the Big Lost River, east-central Idaho: Tucson, Ariz., University of Arizona, M.S. thesis, $41 \mathrm{p}$.

-1991, Quaternary channel changes and paleoflooding along the Big Lost River, Idaho National Engineering Laboratory: Laramie, Wyo., TriHydro Corporation, prepared for EG\&G Idaho, Inc., EGG-WM-9909, 33 p.

Stearns, H.T., Crandall, Lynn, and Steward, W.G., 1938, Geology and ground-water resources of the Snake River Plain in southeastern Idaho: U.S. Geological Survey Water-Supply Paper 774, 268 p.
Stone, M.A.J., Mann, L.J., and Kjelstrom, L.C., 1993, Statistical summaries of streamflow data for selected gaging stations on and near the Idaho National Engineering Laboratory, Idaho, through September 1990: U.S. Geological Survey Water-Resources Investigations Report 92-4196, 35 p.

U.S. Army Corps of Engineers, 1967, Postffood report, flood of June-July 1967, Big Lost River, Idaho: Walla Walla, Wash., U.S. Army Corps of Engineers, $15 \mathrm{p}$. 1991, Feasibility report, Big Lost River Basin, Idaho: Walla Walla, Wash., U.S. Army Corps of Engineers, $25 \mathrm{p}$.

Williams, R.P., and Krupin, P.J., 1984, Erosion, channel change, and sediment transport in the Big Lost River, Idaho: U.S. Geological Survey Water-Resources Investigations Report 84-4147, 87 p.

Wright, A.E., 1903, Report on irrigation in the valley of Lost River, Idaho: U.S. Department of Agriculture Circular No. 58, 43 p. 